\title{
DSM Electricity Savings Potential in the Buildings Sector in APP Countries
}

\section{Stephane de la Rue du Can, Michael McNeil, Virginie Letschert, Bo Shen and Jayant Sathaye}

Environmental Energy Technologies Division

January, 2011 


\section{Disclaimer}

This document was prepared as an account of work sponsored by the United States Government. While this document is believed to contain correct information, neither the United States Government nor any agency thereof, nor The Regents of the University of California, nor any of their employees, makes any warranty, express or implied, or assumes any legal responsibility for the accuracy, completeness, or usefulness of any information, apparatus, product, or process disclosed, or represents that its use would not infringe privately owned rights. Reference herein to any specific commercial product, process, or service by its trade name, trademark, manufacturer, or otherwise, does not necessarily constitute or imply its endorsement, recommendation, or favoring by the United States Government or any agency thereof, or The Regents of the University of California. The views and opinions of authors expressed herein do not necessarily state or reflect those of the United States Government or any agency thereof, or The Regents of the University of California.

Ernest Orlando Lawrence Berkeley National Laboratory is an equal opportunity employer. 


\section{DSM Electricity Savings Potential in the Buildings Sector in APP Countries}

Stephane de la Rue du Can, Michael McNeil, Virginie Letschert, Bo Shen and Jayant
Sathaye

International Energy Studies

Lawrence Berkeley National Laboratory

Berkeley, CA, USA

January, 2011

The work described in this report was funded by the US Department of Energy and the State Department through the U.S. Department of Energy under Contract No. DE-AC02$05 \mathrm{CH} 11231$. 


\section{Table of Contents}

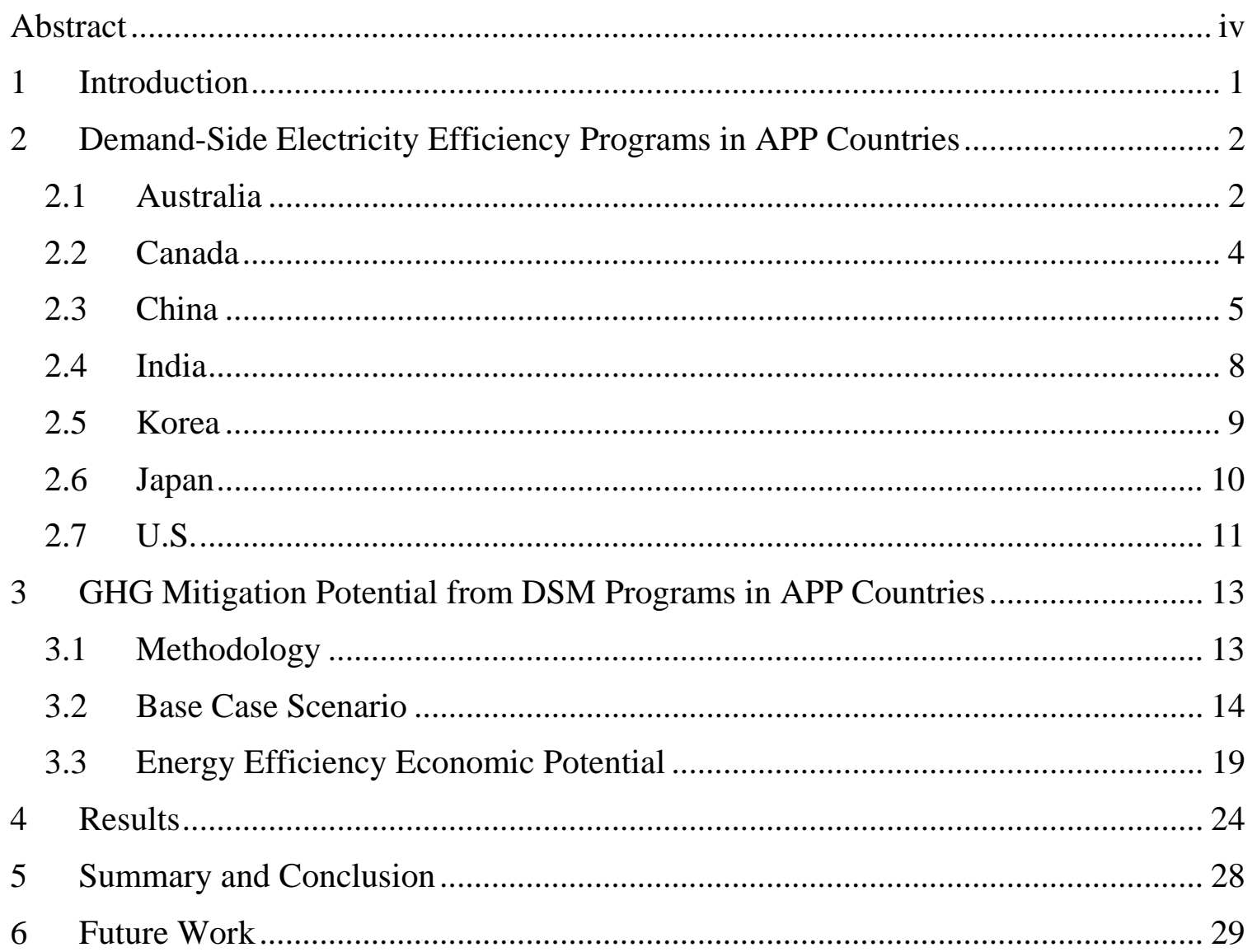




\section{Tables, Figures and Annexes}

\section{Tables}

Table 1. Electricity Tariffs per Country and per Sector, U.S. cents/kWh* .................... 21

Table 2. Efficiency Assumptions for Cost-Effective Targets of DSM Programs -

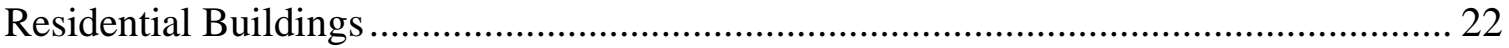

Table 3. Efficiency Assumptions for Cost-Effective Targets of DSM Programs -

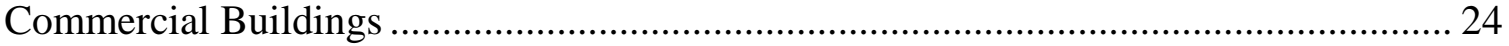

Table 4. Electricity Demand Projections, Energy and Emission Savings Potential..... 25

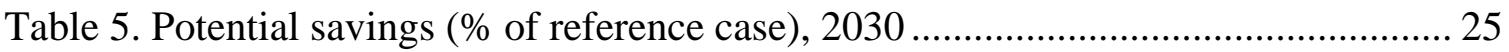

Table 6. Electricity End Use Savings in all APP countries by end use - ....................... 28

Table 7. Electricity End Use Savings in all APP countries by end use - ....................... 28

\section{Figures}

Figure 1. Annual Energy Savings from Efficiency Programs and Standards.................. 13

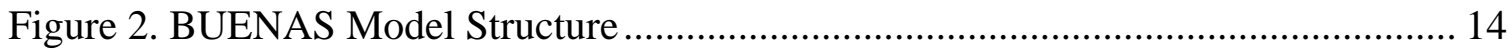

Figure 3. APP Base Case Electricity Demand Forecast -Residential Sector ................... 18

Figure 4. APP Base Case Electricity Demand Forecast - Commercial Sector ................ 18

Figure 5. Comparison of Cost of Conserved Energy for 2010 Standards to Projected

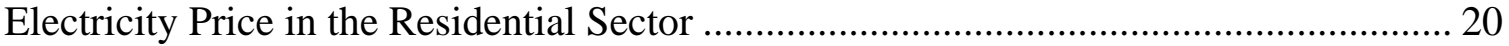

Figure 6. Comparison of Cost of Conserved Energy for Representative 2010 Standards to Marginal Electricity Price in the Commercial Sector .................................................... 20

Figure 7. APP Electricity Savings Potential from DSM Programs - Residential Sector . 26

\section{Annexes}

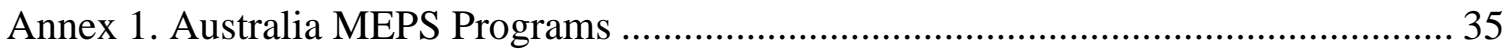

Annex 2. China MEPS and Label Programs................................................................. 36

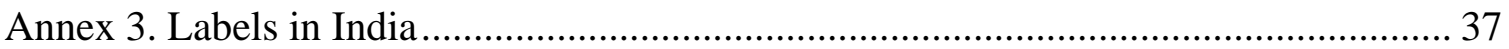

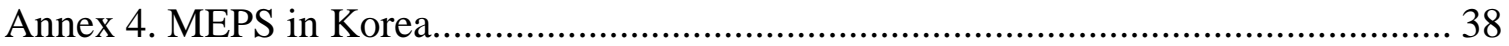

Annex 5. Target Year and Effects of Top Runner Program, Japan ................................. 39

Annex 6. U.S. Appliance Standards (as of September 2005) ........................................ 40

Annex 7. Status of Electricity Restructuring by State in the US .................................. 41 


\begin{abstract}
The global economy has grown rapidly over the past decade with a commensurate growth in the demand for electricity services that has increased a country's vulnerability to energy supply disruptions. Increasing need of reliable and affordable electricity supply is a challenge which is before every Asia Pacific Partnership (APP) country. Collaboration between APP members has been extremely fruitful in identifying potential efficiency upgrades and implementing clean technology in the supply side of the power sector as well established the beginnings of collaboration. However, significantly more effort needs to be focused on demand side potential in each country. Demand side management or DSM in this case is a policy measure that promotes energy efficiency as an alternative to increasing electricity supply. It uses financial or other incentives to slow demand growth on condition that the incremental cost needed is less than the cost of increasing supply. Such DSM measures provide an alternative to building power supply capacity The type of financial incentives comprise of rebates (subsidies), tax exemptions, reduced interest loans, etc. Other approaches include the utilization of a cap and trade scheme to foster energy efficiency projects by creating a market where savings are valued. Under this scheme, greenhouse gas (GHG) emissions associated with the production of electricity are capped and electricity retailers are required to meet the target partially or entirely through energy efficiency activities. Implementation of DSM projects is very much in the early stages in several of the APP countries or localized to a regional part of the country. The purpose of this project is to review the different types of DSM programs experienced by APP countries and to estimate the overall future potential for costeffective demand-side efficiency improvements in buildings sectors in the 7 APP countries through the year 2030. Overall, the savings potential is estimated to be 1.7 thousand TWh or $21 \%$ of the 2030 projected base case electricity demand. Electricity savings potential ranges from a high of 38\% in India to a low of $9 \%$ in Korea for the two sectors. Lighting, fans, and TV sets and lighting and refrigeration are the largest contributors to residential and commercial electricity savings respectively. This work presents a first estimates of the savings potential of DSM programs in APP countries. While the resulting estimates are based on detailed end-use data, it is worth keeping in mind that more work is needed to overcome limitation in data at this time of the project.
\end{abstract}




\section{Introduction}

Growing concerns about climate change, energy supply security and electric system reliability have underlined the need to find new instruments that promote energy efficiency as an alternative to increasing supply. A multitude of policies intending to reduce energy use exist. In the buildings sector, these can be grouped into five categories: standard and labeling programs, financial incentives programs, voluntary agreements, information programs and R\&D programs.

Demand Side Management (DSM) programs, as defined in this paper, refer to the second category and use financial incentives to slow demand growth on condition that the incremental cost needed is less than the cost of increasing supply. Such DSM measures provide an alternative to building power supply capacity The type of financial incentives comprise of rebates (subsidies), tax exemptions, reduced interest loans, etc. Some countries, such as Australia, have also used a cap and trade scheme to foster energy efficiency projects by creating a market where savings are valued. Under this scheme, greenhouse gas (GHG) emissions associated with the production of electricity are capped and electricity retailers are required to meet the target partially or entirely through energy efficiency activities.

Energy utilities are often considered as the best qualified to be involved in the design and implementation of DSM programs. They have ready access to detailed information about the energy consumption patterns of their customers that are needed in determining the most effective projects. Also, they have a direct link with their customers and are often seen by them as a reliable source of information on energy efficiency products and services. However, with the advent of electricity market restructuring in the US and elsewhere in the 1990's, the regulation mechanisms that govern DSM programs have evolved and are still experiencing new adjustments. Unbundling of utilities causes integrated resource planning to become impractical while the introduction of competition reduces the interest of retailers to support demand reduction. Utilities have a financial disincentive to promote customer load reduction given that electricity sales are their main source of revenue and profit. Therefore, new actors and/or new incentives were elaborated to foster resource acquisition programs by utilities. This is especially the case in the US and Canada where intense debates are taking place over the need to create incentives for utilities to implement efficiency programs (US EPA, 2007; EEWG, 2008). Today, DSM programs are administrated by government, independent agencies or utility, or any combinations, while program implementation is mostly done by utilities (Blumstein et al., 2005).

It is worth noting that there does not seem to be a universal definition of DSM programs and hence, care must be taken when employing this terminology. Originally, DSM included measures which increased, as well reduced, the quantity of electricity used by a customer (Crossley, 2004). Nowadays, DSM programs often include energy efficiency measures and load control, load shifting and demand response (DR). In some cases, DSM is a synonym for DR, focusing basically on load shifting, while efforts to rationalize overall consumption are classified as "Efficiency" programs. In this report, we use the term DSM programs to refer to energy efficiency programs that target least-cost options using financial or other incentives that are implemented by utility, independent agency or 
government or any combination of these actors. The energy saving potential of a DSM program is defined as that at which the economic cost of its demand-side measures is lower than the cost of new electricity supply.

DSM programs represent an undeniable policy instrument to reduce energy use by improving the market for the benefit of all. An assessment of their energy savings potential has rarely been conducted. This study attempts to provide an estimate of the potential energy savings of using DSM programs in Asia Pacific Partnership (APP) countries over the mid-term, which we define as up to 2030, by evaluating best practices that are commercially available in some but not necessarily all APP countries. The energy savings potential considered in this report focuses on improvement at the equipment level.

We also evaluate the energy saving potential of DSM programs relative to other policies notably the energy saving potential of minimum energy performance standard (MEPS) programs that are in place today and which could be implemented by 2030 . We limit the scope of our study by omitting building codes from standards policy.

This report is organized as follows: Section 2 provides an overview of energy efficiency programs directed to reduce electricity use in the APP countries. Section 3 describes the methodology used to provide an estimate of the potential energy savings of using DSM programs in APP countries over the mid-term. Finally Section 4 describes and discusses the results provided in this report, and Section 5 discusses the conclusions.

\section{Demand-Side Electricity Efficiency Programs in APP Countries}

Each APP country has implemented measures whose goal is to reduce energy consumption without reducing the energy service or compromising economic development or welfare. This section of the report describes these types of energy efficiency measures that are targeted to reduce electricity consumption in each APP country.

\subsection{Australia}

\subsubsection{Standards and Labeling Programs}

In 2004, the Ministerial Council on Energy of Australia endorsed the National Framework for Energy Efficiency (NFEE) which defines directions for energy efficiency policy and programs in Australia (MCE, 2004). NFEE includes regulatory measures such as new or more stringent minimum energy performance standards (MEPS) for equipment, and minimum energy efficiency design standards for the building code. Other measures are designed to develop awareness of general consumers by requiring audits for large energy consumers and disclosure of building energy performance. Debates surrounding the second phase of NFEE have started in December 2008. One of the most controversial measures discussed is the announcement of a complete phasing out of incandescent lamps by 2009. The first stage of the phase-out plan is the introduction of an import restriction on incandescent general lighting service (GLS) light bulbs used for general lighting purposes from 1 February 2009. This will be followed by an expected retail sales ban from November 2009. From this date 2009, all light bulbs sold will have to meet the new 
minimum energy performance standards of 15 lumens per watt ( $\mathrm{lm} / \mathrm{W})$ (Australia Government, 2009a).

In Australia, energy labeling and MEPS are regulated by the states. However, relevant state legislation is based on a nationally endorsed "model regulation", developed through the National Appliance and Equipment Energy Efficiency Committee (NAEEEC). In 2005, new MEPS levels were negotiated with the industry and these levels are broadly harmonized with US 2001 MEPS levels. Annex 1 provides the list of appliances and equipment with MEPS.

\subsubsection{Financial Incentives}

At the national level, a few programs include financial incentives to promote energy efficiency. The most significant is a rebate of AUD \$1,000 (USD \$840) ${ }^{1}$ for ceiling insulation and solar hot water systems and $\$ 600$ (USD 504) rebates for heat pumps systems. This program was recently redesigned and householders - rather than installers - now will claim the $\$ 1000$ rebate directly to avoid fraud. The Australian Government also provides low-interest loans of up to AUD 10000 (USD 8,403) for renovation implying energy and water savings for CFLs, low-flow showerheads, water trimmers, etc. The program has already helped an estimated 36,000 households and is expected to help over an additional 600,000 (Australia Government, 2010).

At the state level, different energy efficiency programs involve financial incentives. Starting in 1996, Australian electric utilities have been privatized gradually. Today, the electricity market is open and competitive. Australia includes six states that regulate their market. Three of them, New South Wales (NSW), Victoria, and Queensland, have implemented trading schemes that encourage utilities to develop energy efficiency programs. The first one was implemented by the New South Wales in 2003 and was the first mandatory GHG emissions trading schemes in the world. Under this scheme, indirect GHG emissions associated with electricity are capped every year, and electricity retailers have to surrender certificates to partially offset the emissions associated with their electricity sales. In 2007, there were 24.8 million certificates created. Of this, more than $40 \%$ were created by demand-side management programs (IPART, 2008).

Currently, the NSW government is reviewing the possibility of adding a new target to increase energy efficiency activity under the NSW energy efficiency trading scheme (NEET, New South Wales Government, 2008). Retailers will then be required to pursue additional energy efficiency measures in households and businesses. Two other states have implemented targets to reduce GHG but with the requirement to be met only through energy efficiency activities. South Australia State government has implemented the residential energy efficiency scheme (REES) and Victoria State government has implemented the Victorian energy efficiency target (VEET). Both schemes have started on 1 January 2009. Other states have funds allocated to provide rebates to customers and businesses. For example, in Queensland, the smart energy savings fund (AUD \$50 million - USD \$42 million- over five years, 2007-11) provides grants and concessional

${ }^{1} 2008$ average exchange rate of 1.19 AUS \$per US\$ (OECD, 2009) 
loans to assist businesses implementing energy-efficient technologies (Queensland Government, 2009).

\subsection{Canada}

\subsubsection{Standards and Labeling Programs}

Measures encouraging energy efficiency are reflected in the Energy Efficiency Act passed in 1993. Regulations under this Act, in effect since 1995, set minimum energyperformance levels for about 35 energy using products. Amendments of the Act in 2006 extend the coverage to 20 additional products and are tightening requirements for 10 products. The amendments are coming into force between 2007 and 2010 (NRCAN, 2009). Canada also announced a commitment to set performance standards for all lighting that would phase out incandescent light bulbs in common applications by 2012 .

\subsubsection{Financial Incentives}

At the federal level, the Government of Canada has implemented a suite of ecoENERGY Initiatives designed to complement regulatory measures. Among these is the ecoENERGY Efficiency Initiative, which uses approximately \$300 million (USD 280 million $^{2}$ ) to promote smarter energy use, and to support energy efficiency improvements in homes, small buildings and industries.

In the residential sector, the ecoENERGY measure concerns home retrofit. The program consists in hiring a local professional licensed by Natural Resources Canada (NRCan) to perform a detailed, on-site evaluation of the home's energy use from the attic down to the foundation and provides a checklist with recommended retrofits. This is then submitted for grant approval, with a cap of $\$ 5,000$. Most common eligible retrofits include the installation of energy star heating and cooling appliances.

Financial incentives also exist at the regional and local level under the form of rebate, interest-free loan and sales tax exemption. The following table shows programs for refrigerator and space cooling.

\begin{tabular}{|l|l|l|}
\hline 1. Appliances & 2. Provinces & 3. Programs \\
\hline 4. Refrigerators & $\begin{array}{l}\text { 5. British } \\
\text { Columbia }\end{array}$ & 6. BC Hydro Power Smart Fridge Buy-Back Program \\
\hline 7. & 8. Quebec & $\begin{array}{l}\text { 9. Hydro-Québec Household Appliance Rebate - } \\
\text { ENERGY STAR } ® \text { qualified refrigerator or freezer }\end{array}$ \\
\hline 10. & $\begin{array}{l}\text { 11. New } \\
\text { Brunswick }\end{array}$ & $\begin{array}{l}\text { 12. New Brunswick Energy Efficient New Homes } \\
\text { Program }\end{array}$ \\
\hline 13. & 14. Quebec & $\begin{array}{l}\text { 15. RECYC-FRIGO Environmental Program (Hydro- } \\
\text { Québec) }\end{array}$ \\
\hline 16. & 17. Saskatchewan & $\begin{array}{l}\text { 18. Sales Tax Exemption for New Energy-Efficient } \\
\text { Household Appliances }\end{array}$ \\
\hline
\end{tabular}

${ }^{2} 2008$ exchange rate of 1.07 CAN \$ per US\$ (OECD, 2009) 


\begin{tabular}{|l|l|l|}
\hline $\begin{array}{l}\text { 19. Air } \\
\text { Conditioners }\end{array}$ & 20. Ontario & $\begin{array}{r}\text { 21. Horizon Utilities Corporation Peak Saver Program: } \\
\text { Home heating/cooling system purchase/replacement }\end{array}$ \\
\hline & Ontario & Cool Savings Rebate - Ontario Power Authority \\
\hline
\end{tabular}

Source: NRCan , 2010

The regulatory framework that administers and implements them varies across provincial and territorial governments, municipalities, utilities, as well as some non-governmental organizations. For example, in British Columbia, Manitoba and Ontario, where large government-owned integrated hydro electricity utilities prevail, financial incentives programs are part of an integrated resource planning (IRP) approach and are administered by utilities. IPR process requires that the financial incentives programs be considered as an alternative to new capacity building. In other Provinces, such as Alberta and Quebec, the programs are administered by independent agencies but generally implemented by utilities.

There is a resurgence of interest in developing financial incentive programs across provinces of Canada with an interest in moving to a system where the responsibility for programs is separated from utilities and transferred to the regulator or independent agency. An energy efficiency working group (EEWG) was created to provide an expert perspective on energy efficiency in Canada (EEWG, 2008) and to explore new ways of promoting DSM and innovative market-based incentives.

\subsection{China}

\subsubsection{Standards and Labeling Programs}

China's government has expressed strong interest in energy efficiency as a means toward meeting the country's escalating power demand. In 1997, China promulgated the Energy Conservation Law which set energy conservation as a long-term strategy for national economic development. Further impetus was provided by the Eleventh Five Year Plan, which runs from 2006 to 2011. The plan sets an ambitious energy efficiency objective of reducing energy consumption per unit of GDP by $20 \%$ by 2010.

However, most of the focus of current measures in place is directed to the industry sector which represents the largest sectoral energy use. In the building sector, China first adopted minimum efficiency standards in 1989 for eight types of products (Annex 2). Today, standards are set for a wide range of domestic, commercial and selected industrial equipment. This has been further complemented by a mandatory energy information label program launched in 2005 (Annex 2).

\subsubsection{Financial Incentives}

In the past five years, Chinese governments - at both central and provincial level - have made great efforts in incentivizing energy efficiency improvement. Government funding has been utilized to support the launching of the Ten Key Projects, Top-1000 program, elimination of inefficient facilities, and environmental protection measures. The Ministry of Finance (MOF) and National Development \& Reform Commission (NDRC) allocated funding to award ¥200 (US\$29) per tce of saved energy for enterprises in East China and $¥ 250$ (US\$37) for enterprises in Central and West China. To be qualified for the award, 
an enterprise needs to achieve measured savings of at least 10,000 tce (MOF and NDRC, 2007). While national incentives have primarily targeted the large enterprises, provincial and local incentives are focused on smaller enterprises. The Shanghai Municipal Government, for example, awards $¥ 300$ (US\$44) per tce of saved energy to enterprises that have achieved measured savings of between 5,000 tce and 10,000 tce. The Shanghai government is currently considering raising the level of the award to ¥500 (US\$74) per tce of saved energy. 3

As part of the government's nationwide campaign for energy conservation and emission reductions, the Government of China also provides incentive to promote the use of energy efficient products. In 2008, for example, China launched the CFL promotion program to increase the use of energy-efficient light bulbs. In this program, the government offers a 30 percent subsidy on wholesale purchases and a 50 percent subsidy on retail sales of energy-saving light bulbs. A total of 210 million subsidized CFLs were sold to consumers between 2008 and 2009, which had resulted in an estimated savings of 8.8 billion $\mathrm{kWh}$ of electricity each year, a reduction of 8.8 million tonnes of carbon dioxide per year. China plans to subsidize the price to the public of 150 million compact fluorescent light bulbs in 2010. (China Daily, 2010).

In May 2010, the Chinese government extended the incentive program to other products by allocating over 400 billion RMB ( $\$ 60$ billion) annually to promote domestic demands for energy efficient products that include ACs, refrigerators, washers, TV, motors, and computer displays. For example, the central government offers subsidies of 500-850 RMB per unit for grade 1 AC products and 300-650 RMB per unit for grade 2 AC products. Local governments provide additional subsidy of $150 \mathrm{RMB}$ for grade $1 \mathrm{AC}$ units and 100 RMB for grade 2 units. (Wang, 2010)

In June 2010, Chinese government launched a pilot program in five Chinese cities to provide subsidies to buyers of electric and hybrid cars. The domestic incentives provide discounts of 60,000 RMB $(\$ 8,800)$ for electric vehicles and 50,000 RMB $(\$ 7,320)$ for plug-in hybrids. In addition to the new program limited to the five specified cities, Chinese government also offers nationwide subsidies of 3,000 RMB on purchases of cars with 1.6-litre engines or smaller and that consume 20 percent less fuel than current standards. (Reuters, 2010)

In April 2010, the State Council, China’s central government, issued a measure called "Opinions on Accelerating the Promotion of Energy Performance Contracting to Boost the Energy Service Industry," which provides new financial and tax incentives for energy service companies carrying out energy-performance contracting.

China has decades of experience with demand-side management (DSM) programs in power sector. However, its focus has historically been focused on load management through pricing mechanisms such as time-of-use electricity tariffs that create large spreads between peak and off-peak prices, and interruptible pricing that compensate end-

${ }^{3}$ Author's personal communication with staffers at Shanghai Energy Conservation Center 
users for voluntary demand reductions during the peak time. Load management also includes techniques such as peak shaving through which larger customers adjust their production schedules corresponding to peak load in order to reduce peak demand as well as utilization of off-peak storage like ice-storage air conditioners and heat-storage electric boilers (Hu, Moskovitz \& Zhao 2005).

Recent programs in China have extended the focus to improving end-use efficiency and conservation. However, China's approach to energy and demand savings stops at individual retrofit projects. This approach has been unable to encourage local governments and engineering firms to develop enough capacity to identify and implement DSM projects on the sort of scale that they can be used as a programmatic resource. In addition, China faces unique challenges beyond those typical barriers (e.g. lack of capital, lack of access to information, etc.) that are common to energy efficiency programs. Some of China's challenges reside in its inherent power market structure regarding generation pricing and tariff setting methods, while others relate to the lack of legal basis to adopt effective DSM policies and funding mechanisms ${ }^{4}$.

There is a growing trend in China that large-scale, cost-effective DSM programs are developed through the implementation of the Efficiency Power Plant (EPP) - a virtual power plant comprised of a portfolio of demand side management activities. An example of such an approach is the large-scale industrial EPP pilot in China's Jiangsu Province, developed under a California-Jiangsu partnership on energy efficiency improvements. The initial success of the program has caught the attention of the Chinese top leadership, which led to Jiangsu being designed as a model for industrial energy efficiency programs in China (Shen et al., 2009).Financial barriers such as limited access to private capital and commercial loans for energy efficiency improvements are traditionally addressed through incentive funding for energy efficiency projects. As there is currently no centrally authorized DSM funding mechanism, each province must find its own source of funds to support DSM programs. In Jiangsu, for example, the provincial government has been able to negotiate a DSM carve-out from the utility company's operating budget - up to 100 million RMB (equivalent to US\$ 15 million) per year - to provide incentives for industrial DSM programs. However, this funding is determined annually and contingent upon the availability of funds from the utility company, and therefore not guaranteed. (Shen et al., 2009)

In Hebei, the local government collects, on an annual basis, $0.01 \mathrm{RMB} / \mathrm{kWh}$ from a surcharge called urban construction fee that is levied on every customer's electric utility bill and utilizes the money for supporting EPP programs. Shandong has implemented an energy quota system covering 20 industries and 52 products manufactured in the province. The provincial government has set energy use (electricity and other fuels) quota levels. Consumers who exceed the quota level pay a substantial surcharge, as much as $400 \%$ of the energy price. The surcharge is paid to the Shandong Energy Conservation Supervision Center and is deposited in a special fund to be used for energy efficiency. (Moskovitz et al., 2007)

\footnotetext{
${ }^{4}$ For a detailed discussion on barriers to DSM in China, please see Hu, Moskovitz \& Zhao 2005.
} 


\subsection{India}

\subsubsection{Standards and Labeling Programs}

The Energy Conservation (EC) Act, signed in 2001, provides the legal and institutional framework for the government of India to promote energy efficiency across all sectors of the economy. A coordinating body called the Bureau of Energy Efficiency (BEE) was created to implement the EC Act. The need to improve energy efficiency was further emphasized in the National Action Plan on Climate Change (NAPCC), adopted in 2008.

Standards and labeling (S\&L) programs have been identified as one of the key activities for energy efficiency improvement. Labels for five different products have been implemented in 2006 and six additional products are currently being considered and evaluated to be added to the list (Annex 3$)^{5}$. Preliminary discussions have also already taken place with manufacturers of products for setting standards for minimum energy consumption.

\subsubsection{Financial Incentives}

Electricity efficiency programs in India are driven by the need to solve the problem of electricity shortage. Power shortages represent on average $9 \%$ of electricity demand and 14\% of peak load (Pandian G., 2008). An additional 100 GW capacity is needed by 2012 (Pandian G., 2008). In this context, energy efficiency options are among the least-cost options to mitigate the gap between demand and supply. In 2008, the Government released India's first National Action Plan on Climate Change (NAPCC) outlining existing and future policies and programs addressing climate mitigation and adaptation. Fiscal incentives and necessary mechanisms to enhance DSM programs are among the eight national missions for enhanced energy efficiency (NMEEE).

Utility programs in India are voluntary. There is no national prerequisite or state regulation (except in Maharashtra, which recently released new state DSM regulations, and a draft regulation was released by the national Forum of Regulators) requiring a utility to implement energy efficiency programs. Power sector reform in India started in the early 90's, and the sector is still experiencing reforms. The restructuring started with the introduction of private investment in the supply side. Recently the focus of the debate and action has shifted from generation to distribution. Electricity management is organized at the state level. Most of the states have constituted a State Electricity Regulatory Commission and in 2007, about 14 had unbundled their state electricity company (TERI, 2008; Singh, 2006). Along with this current trend in reform are additional debates to further broaden and deepen the process to institutionalize DSM in energy planning.

Several utilities have already implemented some DSM programs. Ahmedabad Electric Company (AEC) has been a pioneer in this domain. Today the utility has several DSM programs among which is included the leasing of energy efficiency equipment to consumers with the help of an ESCO (Prayas Energy Group, 2005). Consumers pay for

\footnotetext{
${ }^{5}$ Stringent MEPS are not yet the focus of the Indian program. However, as the labeling program becomes mandatory, the "one star" rating will constitute an implicit MEPS.
} 
the capital cost over a long period through the achieved savings. The Maharashtra state electricity distribution company recently implemented a DSM pilot program to replace incandescent bulbs with compact fluorescent lamps. Consumers repay the initial cost through the savings achieved by the use of the CFL over a nine month period in utility bills (Singh et al., 2007). Other examples exist but are scattered across India. The Bureau of Energy Efficiency has initiated a national-scale CFL program that is being implemented by a private company and which will acquire CDM carbon credits.

Recently regulators approved new DSM regulation and funding for DSM programs, which resulted in three private utility companies initiating 10 pilot DSM programs on appliances, buildings and the industrial sector. The state of Delhi has also approved funding for such programs and is now developing regulations that will be prepared shortly. Load research is being initiated in West Bengal and Karnataka, which will help the utility companies to target appropriate appliances.

\section{$2.5 \quad$ Korea}

\subsubsection{Standards and Labeling Programs}

The Rational Energy Utilization Act, promulgated in 1979 is the legal framework for energy efficiency enhancement in Korea. The Korea Energy Management Corporation (KEMCO), the government agency directed to implement energy efficiency policy, began its efficiency rating program in 1992. Today, KEMCO is operating three efficiency rating programs:

- $\quad$ the energy efficiency standards \& labeling program which sets MEPS for 19 energy consuming products as well as energy consumption labels (see Annex 4),

- the certification of high efficiency energy-using appliances program which certifies 33 different products for their high energy efficiency performance,

- the e-standby program which is a voluntary program that provides a label for products that decrease electric consumption while in standby.

Furthermore, the Ministry of Knowledge Economy has recently released a long-term National Energy Plan in which it sets a national energy efficiency target of reducing energy intensity by $46 \%$ by 2030 (IEA, 2008). To this end the government intends to increasingly use market mechanisms to determine energy prices, stimulating energy conservation.

\subsubsection{Financial Incentives}

Three distinct financial incentives programs exist in Korea: the low interest rate for investment projects, utility DSM projects and the "Carbon Cashbag" program.

Since 1980, the government of Korea offers long term and low interest rate loans from the Fund for Rational Use of Energy (REUA ) for energy efficiency and conservation investments. The loans are for three to five years and interest rates are about half the current market rates. In 2007, KEMCO provided US \$487 million for the installation of energy-saving facilities (KEMCO, 2009).

In 1995, the Government of Korea revised the REUA (Article 12) to compel utilities to establish and implement a DSM investment plan on an annual basis. This plan is then 
submitted to the Government for review. As a consequence, Republic of Korea Electric Power Corporation (KEPCO), Republic of Korea Gas Corporation (KGC) and Republic of Korea District Heating Corporation (KDHC) have invested a considerable amount of funds in DSM every year. Programs encourage the widespread use of high-efficiency devices, by providing rebates whose costs are included in the utility operating total cost (Vine et al., 2006).

Recently, in October 2008, a new initiative called the "Carbon Cashbag" system has been launched by the government to promote energy efficiency. The system awards carbon points to consumers for every high-efficiency electronic and electrical appliance they buy. These points are stored on a Carbon Cashbag card and can then be used for discounts on public transportation, basic utilities charges, buying other appliances or when attending cultural events. The system will cover 33 electronic goods. It is a voluntary program where companies that register benefit by receiving reductions in advertising fees and other public incentives (IEA, 2008).

\subsection{Japan}

\subsubsection{Standards and Labeling Programs}

Japan has a long tradition in promoting energy efficiency. The Energy Conservation Law (also known as Law concerning Rational Use of Energy) passed in 1979, and was amended on several occasions, the latest being in 2005. This law aims at contributing to the sound development of the national economy through implementing necessary measures for the rational use of energy.

The backbone of the energy efficiency measures is the "Top Runner Program”, first implemented in 1999 and last revised in October 2006. The program covers 21 items and the estimated energy savings are presented in Annex 5.

In May 2006, the necessity of increasing energy efficiency was reinforced in the New National Energy Strategy to expand Japanese energy security and encourage energy efficiency measures in the commercial/residential and transport sectors. The National Energy Strategy aims at improving the efficiency of energy consumption at least by an additional $30 \%$ by 2030 .

\subsubsection{Financial Incentives}

The government has adopted a range of tax and subsidy schemes to promote energy efficiency across sectors. The government provides subsidies for business operators and households introducing energy-efficient systems for their new buildings or extensions.

Deregulation of the Japanese electricity market has been fairly gradual. It started in 1995 and, by 2008 about $63 \%$ of the electricity sold was open to the market (for customers above $50 \mathrm{~kW}, 6 \mathrm{kV}$ ). However, Japan's electricity industry is still dominated by the 10 regional utilities that are now privately-owned integrated power companies, the largest of which is the Tokyo Electric Power Company (TEPCO), which accounts for 32\% of total power generation in the country.

Utility DSM programs in Japan are confined to valley filling, load shifting and peak clipping. Utilities have budgets for energy efficiency technologies research and 
development, like for heat pump water heaters. The objective is to improve the service to the customer and increase the penetration of electricity equipment.

In 2009, the Japanese government launched the Eco-Point System as part of Japan’s stimulus package a program. This program grants 'eco-points' for the purchase of consumer products that rate four or more stars in the national system of energy-efficiency standards. Three kinds of consumer products are considered: air conditioners, refrigerators and TVs. More points can be gained by handing over old consumer products for recycling. Eco points are then redeemed for gift certificates, prepaid cards for travel or gift coupons issued by major department stores. The time limit for appliance purchase was originally March 2010 but has since been extended until December, 2010. By the end of June 2010, the government had granted 246 billion eco-point, equivalent to 246 billion yen ( $\$ 2.6$ billion $\mathrm{USD}^{6}$ ) (METI, 2010). The Japanese government is also planning on launching a similar system for housing energy efficiency improvement where households who remodel their house with better insulation and other energy-efficiency improvements, or build a new eco-friendly house will be granted eco-points. (Hosaka, 2010).

\subsection{U.S.}

\subsubsection{Standards and Labeling Programs}

Minimum energy efficiency standards were first introduced in the state of California after the first oil crises of 1974. Several other states quickly followed, leading the federal government to develop national standards for 13 residential household appliances in 1978 under the National Energy Policy and Conservation Act (NEPCA). The Energy Policy Act of 1992 expanded the coverage of these efficiency standards to certain commercial and industrial equipment. From 1987 to date, US appliance standards have been implemented on 40 product types (Annex 6). Eighteen updates have been implemented on 14 product types; some product types have had more than one update since the original standard (clothes washers, refrigerators and freezers, fluorescent lamp ballasts). DOE plans to issue 23 additional rulemakings for new or updated standards, all by August, 2011

\subsubsection{Financial Incentives}

In the US, the power sector is decentralized and legislation is done at the state level. There are no federal efficiency mandates on electric and gas utilities. It is up to each state and/or utilities to choose how much energy efficiency is appropriate. About half of the states have passed legislation to restructure their electric power industry. However, only 14 of them have a market fully restructured where consumer can choose their provider, 8 have suspended their restructuring and 28 have not passed any legislation in favor of deregulation (see Annex 7). The restructuring has focused most attention over the 1990's, which led to a decline in DSM programs. However, with increasing pressure on environmental issues, energy security and reliability, there has been a revival of interest in developing DSM programs to improve energy efficiency.

\footnotetext{
${ }^{6} 2009$ exchange rate of 93.57 Yen per US\$ (OECD, 2009)
} 
Mainly three challenges face states desiring to encourage utility energy efficiency programs (US EPA, 2007). First, states need to introduce mechanisms allowing the recovery of cost of energy efficiency programs, such as cost associated with the administration, implementation and evaluation of programs. About 32 states currently offer energy-efficiency programs funded by utility ratepayers and/or system benefit funds (US EPA, 2007). The second challenge consists in removing utility disincentives due to "lost revenue" that results from energy efficiency programs. This can be done through lost revenue adjustment mechanisms (LRAMs) which compensate the utility for its lost revenue or by eliminating the relationship between sales and revenue through decoupling mechanisms. In the US, about six states have implemented LRAMs while 14 have chosen the decoupling approach (US EPA, 2007). Finally, the third challenge consists in creating incentives for the utility to implement energy efficiency programs. About 18 states have used the performance incentives that create earnings potential from energy efficiency program investments. This mechanism has been used in 18 states (US EPA, 2007).

Energy efficiency DSM programs are structured in many different ways across the US and some states are still debating which mechanism to implement. Moreover, in some states DSM programs are administrated by utility while in other states they are administrated by an independent agency or government agency (Blumstein et al., 2005). Finally, DSM programs across the states also vary by their scope. Some have limited funding and focus on DR rather than energy efficiency DSM. In their state-by-state analysis, the ACEEE found that the five states with successful utility DSM programs were Vermont, Connecticut, California, Oregon and Minnesota (Eldridge et al., 2008). California has a long history in implementing utility DSM programs and established itself as a leader in promoting energy efficiency in the US.

Utilities started to implement utility DSM programs in the early 70's in California. A recent study conducted by the California Energy Commission (CEC, 2005) shows the annual energy savings from California's energy efficiency programs and standards since 1975 (see Figure 1). About half of California's energy savings have come from utility DSM programs, while the other half have come from building and appliance standards. Through 2003, these policies have accumulated about 40,000 GWh of annual energy savings and 12,000 megawatts of peak electricity, equivalent to 24 500-megawatt power plants (CEC, 2005). The CEC study also looks at cost effectiveness of utility programs, measured by energy savings for each dollar spent and finds that electricity saved per dollar spent appears to have stabilized at an average of $4.75 \mathrm{kWh}$ per dollar, or $\$ 0.021$ per kWh since 1998. In September 2005, the CPUC approved the 2006-2008 investorowned utility energy efficiency plans. Over 3 years, approximately $\$ 1.7$ billion was invested in electricity energy efficiency. 
Figure 1. Annual Energy Savings from Efficiency Programs and Standards

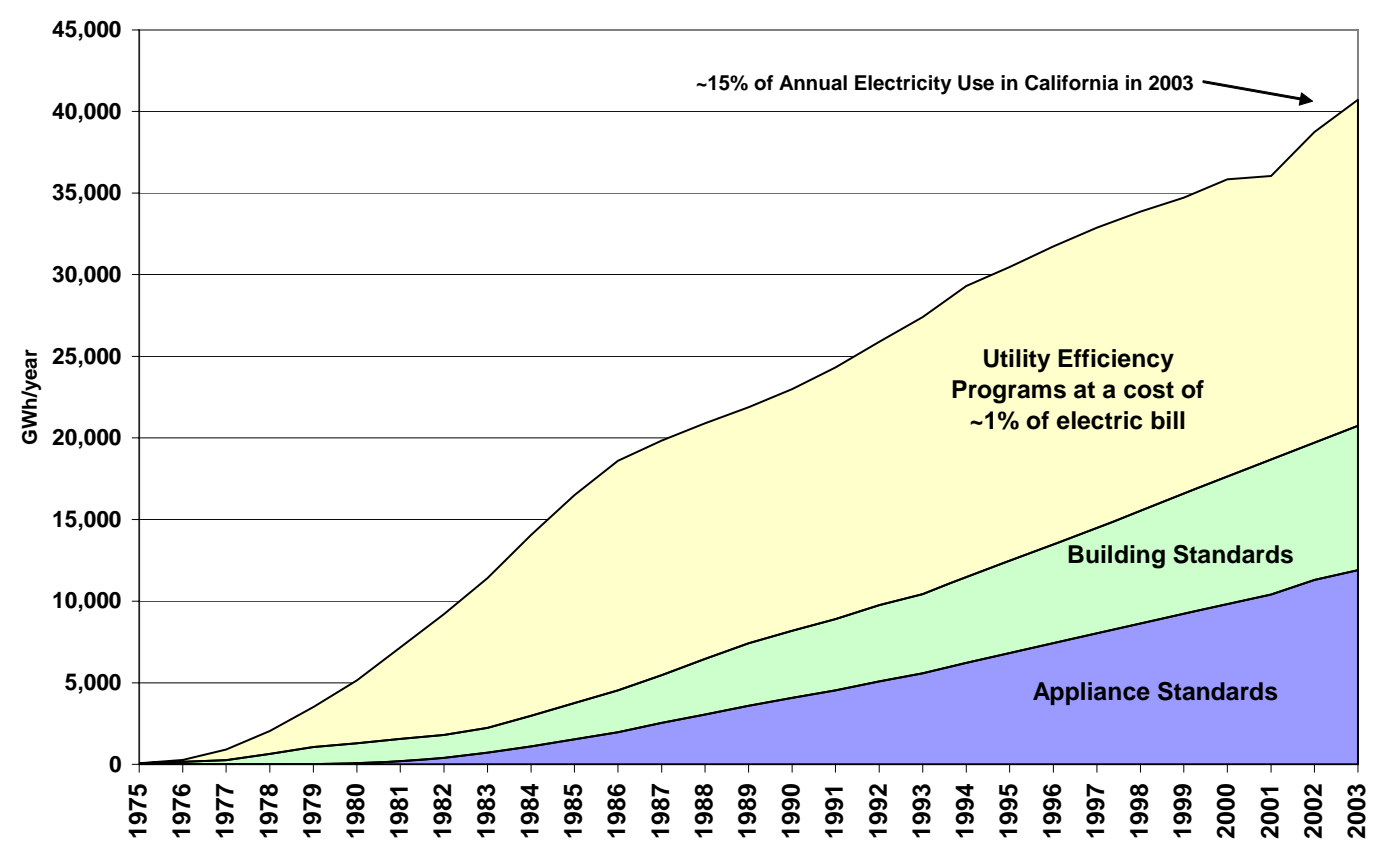

Source: CEC, 2005.

\section{GHG Mitigation Potential from DSM Programs in APP Countries}

In this section, we estimate the potential savings available to DSM energy efficiency programs, in terms of site electricity, and carbon dioxide emissions reductions. The general approach for estimating savings potential from DSM programs is to identify costeffective maximum efficiency levels and create a scenario by which DSM programs transform the market for equipment toward these levels. In identifying efficiency levels, the strategy is to be as specific as possible, focusing on individual end uses and, in some cases, technologies. An effort is also made to characterize current baseline technologies, and the variation of these between countries.

\subsection{Methodology}

Estimates of impacts from DSM programs are made using a bottom-up forecast of electricity demand in the buildings sector developed by LBNL, called the Bottom-up Energy Analysis System (BUENAS). BUENAS calculates energy demand for most end uses and equipment types in the residential and commercial sectors. The model constructs the analysis in a modular way as shown in Figure 2. The first module models demand for energy services (activity) at the end use level, while a second considers the final energy used to provide those services in the base case, and builds efficiency scenarios based on meeting equipment efficiency targets by a specified year. A third module tracks market penetration and stock turnover for efficient products. Finally, these three components are brought together, and savings are calculated as the difference in consumption and emissions in the efficiency scenario versus the base case. 
Figure 2. BUENAS Model Structure

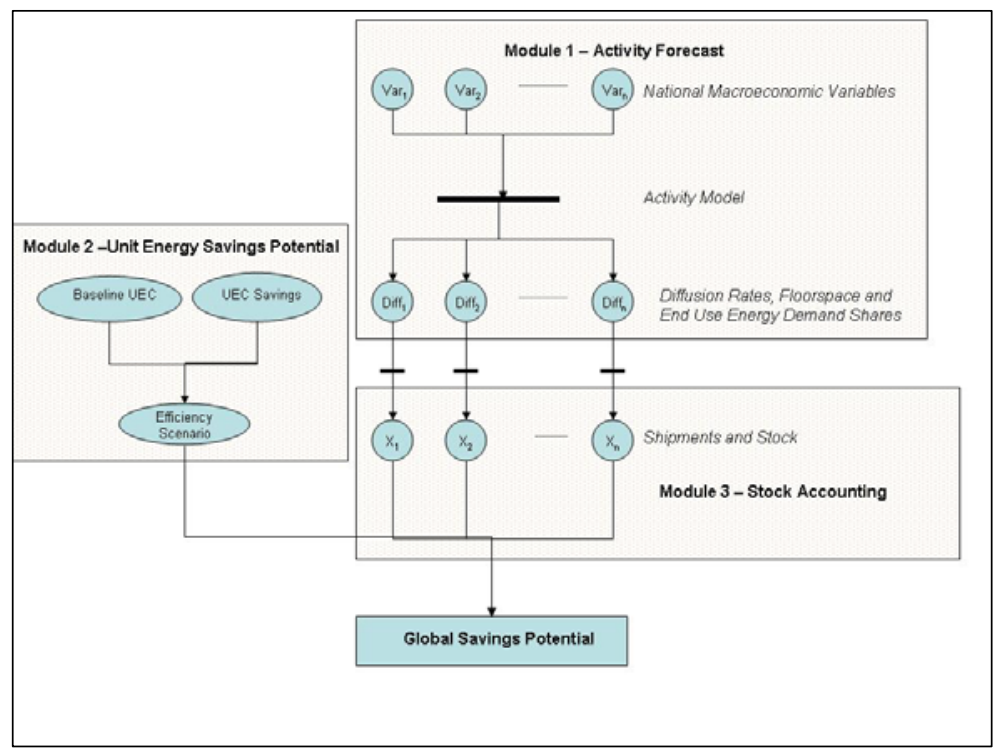

BUENAS is a global model, covering most of the world's countries, grouped into 10 regions. For this study, the model was modified to be limited to the APP countries, and to contain as much detail for each as was available.

The first step in modeling energy demand consists in forecasting activity. In households, activity is described in terms of ownership of energy-consuming equipment and lighting. In the commercial sector, it is given in terms of the density of equipment per unit area of floor space. The development of the equipment diffusion (ownership rate) and commercial floor space models is described in detail in McNeil et al. (2008). For the residential sector, equipment diffusion growth is modeled as a function of income, electrification and urbanization. For the commercial sector, floor space growth was broken down to two factors driven by economic growth (GDP) and population: the share of workers employed in the commercial sector and the amount of floor space $\left(\mathrm{m}^{2}\right)$ per employee. For consistency, we chose the GDP growth forecast provided for each country by a single model, the US Department of Energy's International Energy Outlook 2007 (USEIA 2007).

\subsection{Base Case Scenario}

Energy demand through 2030 is forecast by considering the unit level consumption of electric ${ }^{7}$ end uses, and scaling them up to the national level. The detailed end uses are as follows:

\section{$\underline{\text { Residential End Uses }}$}

- Incandescent Lamps

\footnotetext{
${ }^{7}$ For the purposes of this study, we assume that DSM programs will primarily target electricity consumption.
} 
- Fluorescent Lamps

- Refrigerators

- Ovens

- Standby

- Washing Machines

- Televisions

- Space Cooling

- Electric Water Heating

- Fans

- Electric Space Heating

\section{Commercial End Uses}

- Lighting

- Space Cooling

- Refrigeration

- Ventilation

- Office Equipment

- Electric Space Heating

Total national electricity demand from each end use in each sector is calculated by combining the activity forecast from Module 1 of BUENAS, with the Baseline unit energy consumption (UEC) from Module 2. Base case electricity demand $E^{0}$ for each residential end use is given by:

$$
E^{0}{ }_{i}(\text { year })=\text { Diff }_{i}(\text { year }) \times \text { Households }(\text { year }) \times U E C_{i}(\text { year })
$$

In this equation, $i$ is the end use index (e.g. refrigeration), Diff $f_{i}$ is the diffusion (number of appliances per household) and $U E C_{i}$ is the baseline unit energy consumption. The diffusion is forecast as a function of macroeconomic variables, according to a separate econometric relationship for each end use (for more details, see McNeil et al., 2008). For the commercial sector, base case electricity demand is given by

$$
E_{i}^{0}(\text { year })=F(\text { year }) \times \text { Penetration }_{i}(\text { year }) \times E U I_{i}(\text { year })
$$

Commercial end-use consumption is proportional to $F$, the total commercial floor space, Penetration $_{i}$, the level of penetration of each end use per square meter of floor space, and $E U I_{i}$, the intensity $\left(\mathrm{kWh} / \mathrm{m}^{2}\right)$ for each end use. The activity variables, $F$ and Penetration $_{i}$ are functions of economic growth (GDP per capita).

Base case unit energy consumption (UEC) is calculated according to a combination of current standards (MEPS) applied in each country, or from engineering estimates of equipment representing the market baseline. Where available, data specific to each country are used, otherwise assumptions are made based on prevailing trends in the international market. For a complete detail of the original dataset used by country, see McNeil et al. (2008). Base Case UEC assumptions are summarized in Tables 2 and 3. 


\section{$\underline{\text { Residential End Uses }}$}

Incandescent Lamps - Incandescent lamps are considered generically in all countries. A $60 \mathrm{~W}$ bulb is taken as characteristic of incandescent lighting.

Fluorescent Lamps - Current efficiency for Australia, Canada, Japan, Korea and the United States based on electronic ballasts. Improvement is from high-efficiency ballast/lamp combinations. The baseline in China and India are low-efficiency magnetic ballasts.

Refrigerators - UEC values are based on current MEPS in Australia, Canada, China, Korea and Japan. Estimates for India are based in engineering estimates and current testing data.

Ovens - Base Case electric oven consumption for the U.S. and Canada based on current MEPS and engineering estimates. Estimates for Australia, Japan and Korea are taken from Japanese estimates. Electric ovens are not common in China and India, and are not covered.

Standby Power - A baseline of 5W per product is assumed for all products consuming standby, in all countries.

Washing Machines - Washing machine baseline energy for Australia, Canada, Japan, Korea and the United States are based on current MEPS. UEC for Chinese washers is based on current estimates of the market baseline. Indian washer UEC are based on international averages, assuming a combination of semi-automatic and horizontal axis washers.

Televisions - Television baseline UEC is assumed to be equal in all countries, and is based on prevailing trends and forecasts of technology-type market share.

Space Cooling - Air conditioner baseline efficiency and consumption are based on current MEPS for Australia, Canada, China, Korea and Japan. Estimates for India are based on current test data.

Electric Water Heating - Electric water heater efficiency is based on current MEPS for Canada and the United States. For the other countries, we assume that electric water heaters currently perform at a particular level of efficiency as defined by the European Union efficiency label. For Australia, Japan and Korea, we assume efficiency equal to the EU ' $E$ ' level. For China and India, we assume a baseline at the EU ' $G$ ' level.

Fans - Fan baseline efficiency is based on current estimates of the U.S. baseline. There are currently no MEPS for fans.

Electric Space Heating - Baseline efficiency for electric resistance heating is assumed to be $100 \%$. For heat pumps, efficiency corresponds to current MEPS for heat pumps; otherwise, heat pump efficiency is assumed to be equal to air conditioner cooling efficiency.

\section{$\underline{\text { Commercial End Uses }}$}

Lighting - Commercial lighting efficiency is based on estimates of technology mix, including fluorescent ballast type and lamp type (see McNeil, 2008). 
Space Cooling - Commercial Space cooling efficiency is based on estimates of the mix of chillers, package/split units (central air conditioning), and room air conditioning in each country. Package unit air conditioning is considered for Australia, Canada and the United States, where the baseline is assumed to meet the current U.S. baseline. Split systems are considered for Japan, Korea, China and India, and are assumed to meet a baseline according to the current EU 'E' level (proposed). Chiller efficiency meets current MEPS in the U.S. and Canada. In Australia, Japan, and Korea, chillers are assumed to meet EU ' $\mathrm{A}$ ' levels, and in China and India, they are assumed to meet $\mathrm{EU}$ ' $\mathrm{E}$ ' levels.

Refrigeration and Ventilation- Refrigeration and ventilation efficiency is considered generically. Baseline energy intensity (including efficiency) is estimated from regional level data.

Office Equipment - Office equipment is assumed to have a baseline standby usage of $5 \mathrm{~W}$ per piece of equipment.

Electric Space Heating - Electric Space Heating is rare in the commercial sector, except in the United States and Japan, where heat pumps are used. For these, heat pump space heating efficiency is assumed to be equivalent to cooling efficiency.

Figure 3 and Figure 4 show for APP countries projections of electricity demand for the residential (Figure 3) and commercial sector (Figure 4) broken down at the end use level resulting from BUENAS model. The results are compared with a projection from another international modeling effort, the IEO (US EIA, 2008).

In general, total demand estimates are quite close to the top down IEO forecast, and we made no calibration. In a few cases, however, we made calibrations in order to avoid large errors in savings estimates. Calibration factors were applied to individual end uses in the case of Australia, by comparing 2007 estimates of demand to Australian data ${ }^{8}$. As a result, total electricity consumption was boosted by a factor of 2.3 for lighting, 1.81 for space cooling, 0.5 for space heating, and 1.89 for televisions. In the commercial sector, calibrations were applied at the sub-sector level for two countries. A factor of 1.66 was applied to commercial floor space for Canada, and 1.91 for Korea.

\footnotetext{
${ }^{8}$ Available at http://www.environment.gov.au/settlements/energyefficiency/buildings/publications/pubs/energyusepart1.pdf
} 
Figure 3. APP Base Case Electricity Demand Forecast -Residential Sector

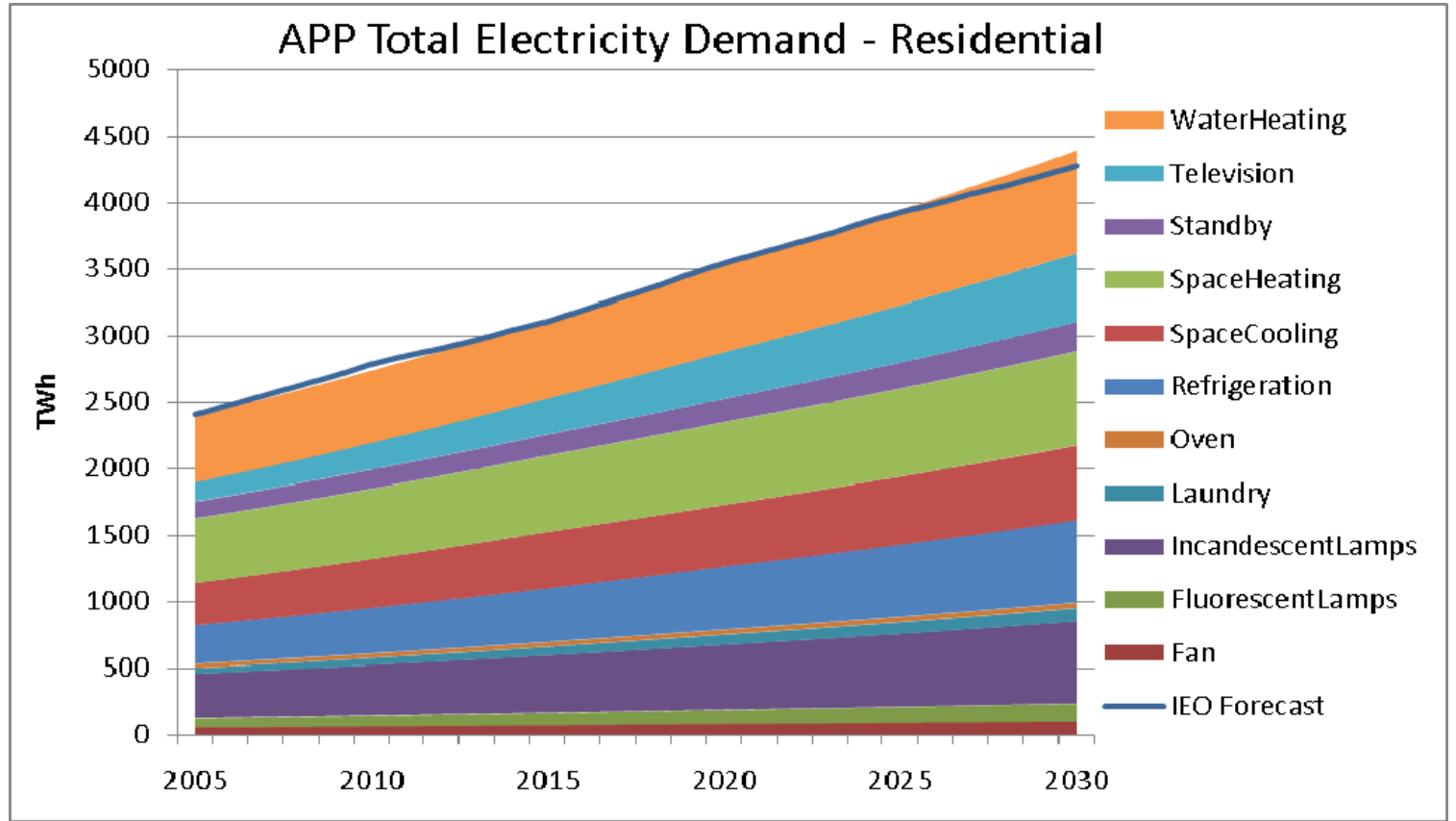

Figure 4. APP Base Case Electricity Demand Forecast - Commercial Sector

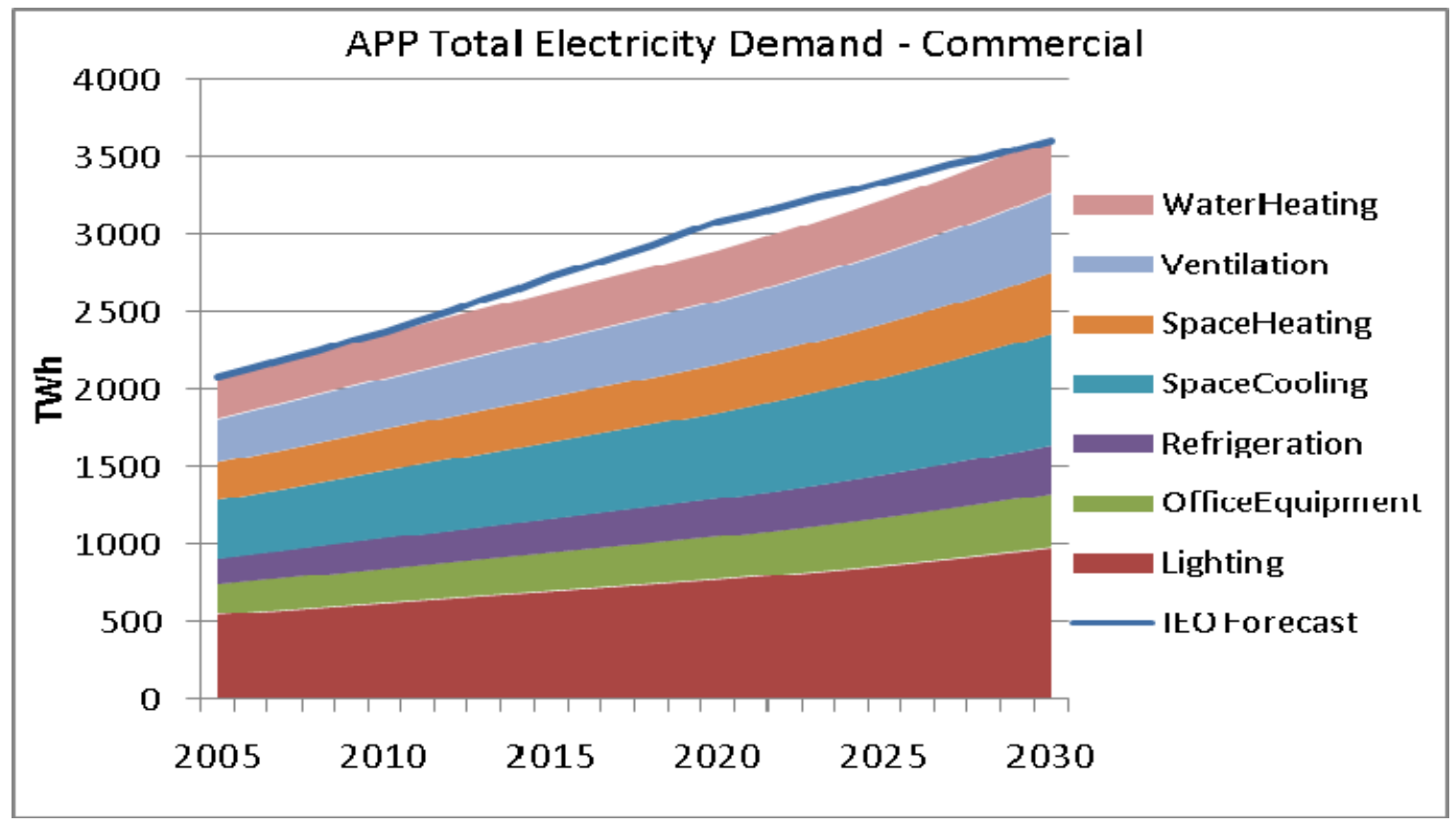

Two general conclusions can be made regarding the buildings electricity demand forecasts for APP countries. First of all, comparison to the IEO reference forecast (a top down forecast) reveals that the large majority of electricity consumption is accounted for by well-defined, and relatively well understood end uses and equipment types specified in the bottom-up model. This means that technology-specific efficiency programs that utilize engineering and cost analysis, if applied comprehensively, could impact a large 
fraction of the electricity use in this sector. Secondly, in both the residential and commercial sub-sectors, electricity use is distributed relatively evenly across a range of enduses in the APP countries. This implies that programs seeking to make significant inroads toward cost-effective electricity demand reductions should cast a relatively widenet to capture as many different main technologies as possible.

\subsection{Energy Efficiency Economic Potential}

It is clear that for all of the APP countries, and for most of the end uses studied, there is significant opportunity for reduction of electricity demand and greenhouse gas emissions mitigation through efficiency improvement. There are several policy mechanisms which facilitate the transformation of equipment markets and installed stock to a more efficient scenario. These include: mandatory efficiency standards, voluntary manufacturer efforts, labeling and information programs, price-based policies, as well as programs traditionally put in place by utility DSM efforts, such as equipment price subsidies, etc.

In fact, significant efforts to reduce greenhouse gas emissions are likely to be successful only if they include a variety of these efforts. The effects of different policy types and programs are difficult to disentangle, so we do not attempt it here. Instead, we put for a scenario for efficiency improvement that is not specific to a particular implementation scheme, but instead uses a consistent metric at the end use level to describe a reasonable target. The metric we use is cost effectiveness to the consumer, taking into account increased equipment cost, offset by reduced utility bill payments over the life of the appliance. In order to evaluate appropriate cost-effective targets, we rely heavily on previous research performed by LBNL on the cost effective potential for improvement in the U.S. residential and commercial buildings sector (Rosenquist et al., 2006).

The Rosenquist et al (2006) study used engineering and cost data to determine the efficiency level of equipment that would provide the minimum incremental life-cycle cost, relative to the current baseline in the United States. Only those options that provided a net financial gain to consumers were considered. For each end use, the cost of conserved energy was calculated according to the following formula:

$$
C C E=\frac{\Delta E C}{\sum_{y=1}^{L} \Delta U E C \times(1+D R)^{-y}}
$$

In this equation, $\triangle E C$ is the increase in equipment cost for the higher efficiency product, and $\triangle U E C$ is the annual reduction in electricity consumption. The energy factor in each year is multiplied by a discount factor determined by the consumer discount rate $D R$, to yield the present value of energy savings. The summation in the denominator is over the useful life of the equipment. Figures 3 and 4 below show samples of the cost of conserved energy for selected products as determined by (Rosenquist et al. 2006). 
Figure 5. Comparison of Cost of Conserved Energy for 2010 Standards to Projected Electricity Price in the Residential Sector

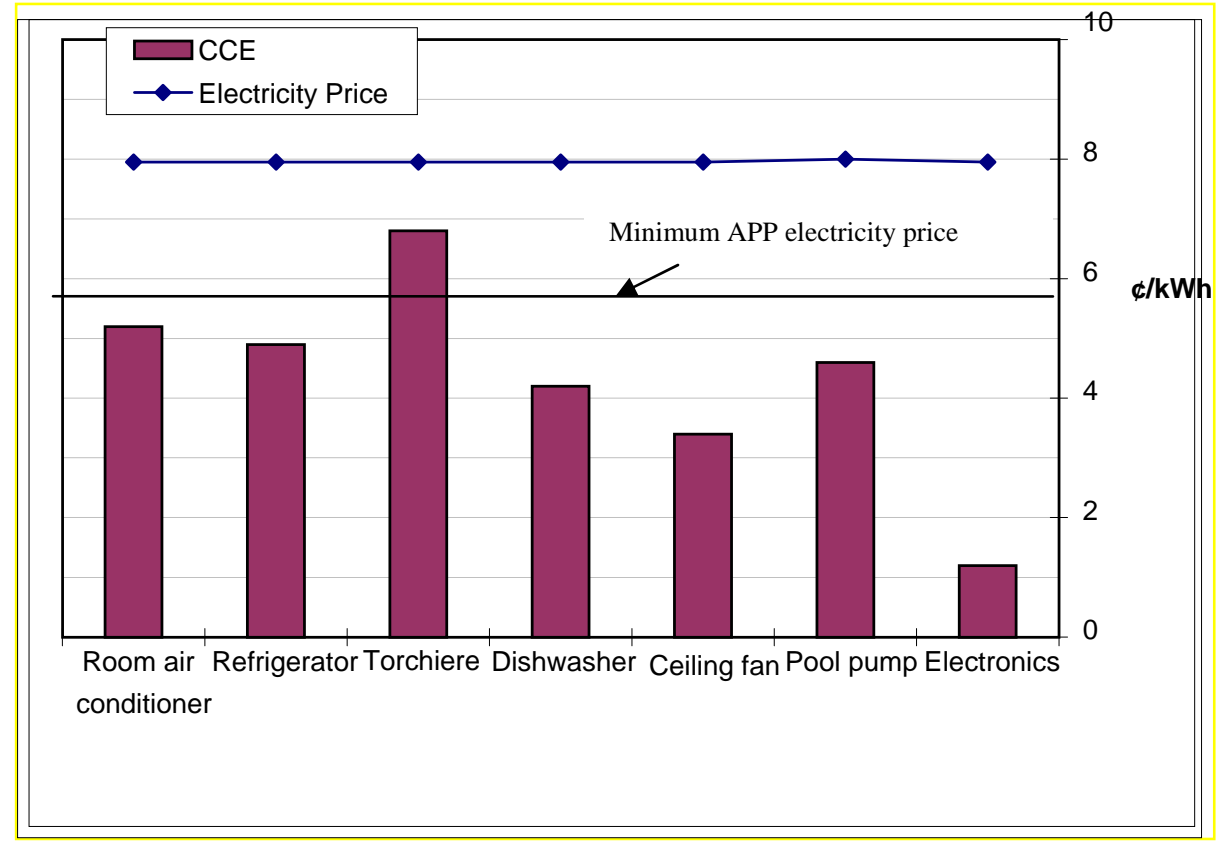

Source (Rosenquist et al. 2006)

Figure 6. Comparison of Cost of Conserved Energy for Representative 2010 Standards to Marginal Electricity Price in the Commercial Sector

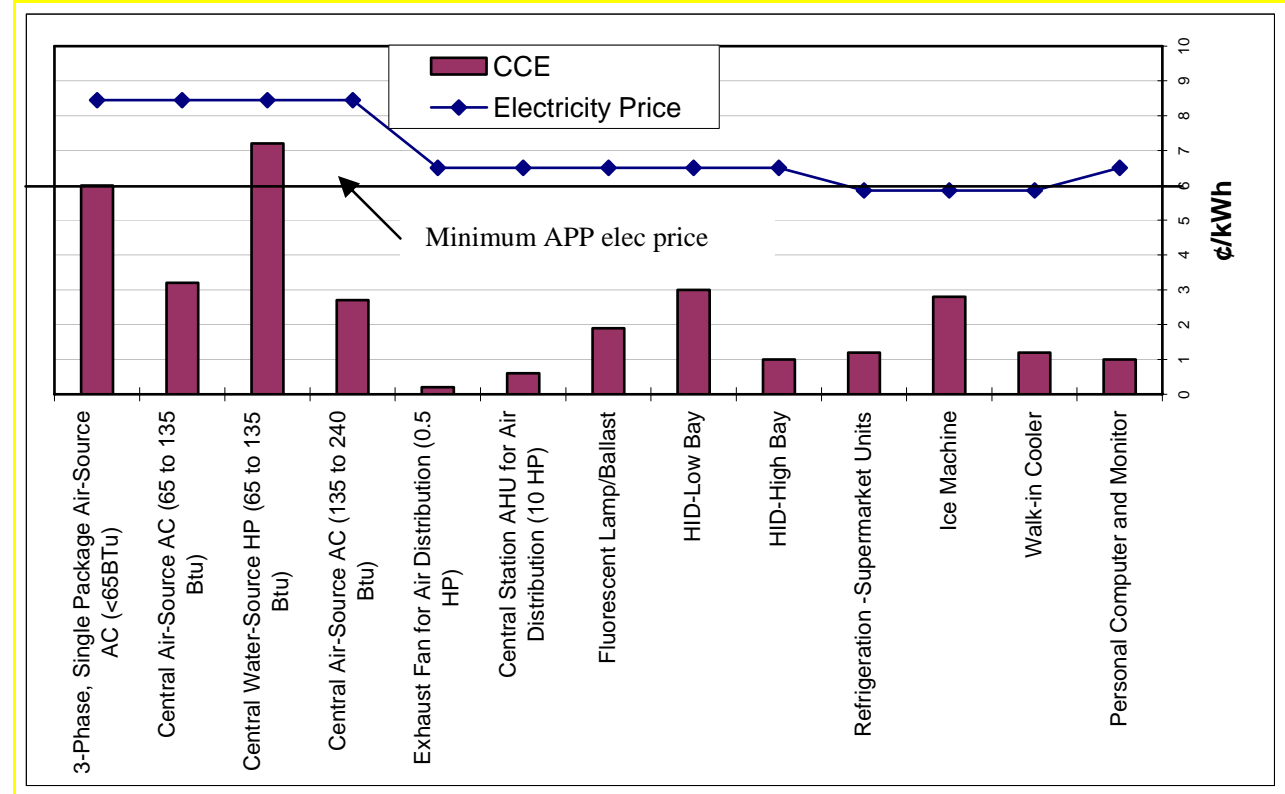

Source (Rosenquist et al. 2006)

In the extension of the U.S. cost-effectiveness analysis to all APP countries, two tacit assumptions are made: 
- That technologies found to be cost-effective in the U.S., will also be cost-effective in other APP countries.

- That technologies found to be cost-effective relative to the U.S. baseline technology, will also be cost-effective relative to the baseline technology in other APP countries.

The range of electricity prices indicates that, given equivalent equipment price increases, the targeted technologies are likely to prove cost effective across APP countries. Table 1 shows national average electricity tariffs per APP country. Electricity prices in APP countries vary by end users, monthly load consumption, grid and region or states. The range of electricity prices indicates that, given equivalent equipment price increases, the targeted technologies are likely to prove cost effective across APP countries. CCE lies in the range of 2 cents/kWh to 5 cents/kWh for most residential technologies and from 1 cent/kWh to 6 cents/kWh for commercial technologies ${ }^{9}$, (see Figure 5 and Figure 6 ). These costs are lower than electricity prices in the appropriate sector for all APP countries, indicating cost-effectiveness. Prices are based on national averages for the most recent year available as shown Table 1 and have been converted in 2004 constant prices and 2004 US dollar to allow better comparison with the CCE that was calculated for the year 2004. National average electricity tariffs range from $5.6 \mathrm{US}$ cents/kWh in China to 19.7 US cents/kWh in Japan for residential consumers and from 5.9 US cents/kWh in Australia to 13.0 US cents/kWh in Japan. Japan has by far the highest tariff making the range of energy efficiency options that are cost effective even larger that what is considered in this study.

Table 1. Electricity Tariffs per Country and per Sector, U.S. cents/kWh*

\begin{tabular}{|l|r|r|ll|}
\hline & Residential & Commercial & Year & Source \\
\hline Australia & 9.6 & 5.9 & 2004 & IEA, 2009 \\
\hline Canada & 6.8 & 7.9 & 2006 & Canada EEO, 2009 \\
\hline China & 5.6 & 8.1 & 2008 & LBNL, 2009 \\
\hline India & 6.0 & 7.4 & 2007 & India MOF, 2008 \\
\hline Japan & 19.7 & 13.0 & 2007 & IEA, 2009 \\
\hline Korea & 8.0 & 8.3 & 2005 & Shenoy et al. 2008 \\
\hline United States & 9.8 & 8.5 & 2007 & EIA, 2009 \\
\hline
\end{tabular}

* Conversion to 2004 prices using GDP deflator (IMF, 2008) and conversion in US cents using the 2004 exchange rate (OECD, 2009)

**Calculated as an average across regions/states

While we believe that the evaluation of cost effectiveness made for the United States is likely to have wide validity across the other APP countries, it is useful to make note of the uncertainties in this assumption, and the limitations of the methodology. Most importantly, equipment cost data is generally not available for other countries. A more robust study would require collection of this type of data in order to construct costefficiency curves on a country-by-country basis, a research project that is highly desirable, but beyond the scope of this study. Secondly, while average prices are

\footnotetext{
${ }^{9}$ See (Rosenquist 2004) for details of CCE for all products studied.
} 
indicative of the cost of electricity delivery and the level of subsidization (or crosssubsidization across sectors), a more appropriate indicator of cost effectiveness uses the marginal cost of electricity, that is the cost of the last kWh used (and thus saved by efficiency measures). Finally, the definition of appropriate discount rates deserves more attention than can be given here, and is highly variable between countries and electricity customer types. It should also be noted that additional technologies may now be available and available in the coming years which were not well-known or widely commercialized at the time of the original study. A reinvestigation and update of the equipment cost-efficiency curves is therefore likely to yield higher estimates of costeffective potential.

Given the assumptions described above, an efficiency scenario is constructed at the end use level for each country. The determining parameters for energy consumption are the current base case efficiency level or UEC, and cost-effective target efficiency (Table 2). The total savings/mitigation potential is defined as the situation where $100 \%$ of the market (sales) for each equipment reaches the target level by 2010, and is constant thereafter. Baseline efficiency and cost-effective targets are given in Table 2 for the residential sector and Table 3 for the commercial sector.

While in principle, the efficiency scenario includes the same target technology for all countries, in practice, there are several reasons for variability in target efficiencies and/or $U E C / E U I$. First, there are differences in product capacity and class, such as differing sizes of residential refrigerators across countries. Second, end uses are composed of different configurations of equipment type - central air conditioning dominates in the U.S. and Canadian residential sector, while room air conditioners are more common elsewhere. Another important example is commercial lighting, where the mix of lighting equipment varies among countries. Finally, hour of use of equipment also differ widely between countries and contribute to determine the UEC. For example, one of the reasons why commercial lighting intensity is so high in the US is due to the fact that lights are on longer than in any other country. For more details on the derivation of baseline efficiency estimates and achievable targets, see (McNeil 2008).

Table 2. Efficiency Assumptions for Cost-Effective Targets of DSM Programs Residential Buildings

\begin{tabular}{|c|c|c|c|c|c|}
\hline Enduse & Region & Units & $\begin{array}{l}\text { Base Case } \\
\text { Average } \\
\text { Efficiency }\end{array}$ & $\begin{array}{c}2010 \text { Cost } \\
\text { Effective } \\
\text { Target }\end{array}$ & Assumption \\
\hline $\begin{array}{l}\text { Incandescent } \\
\text { Lamp }\end{array}$ & All & Watts & 60 & 15 & half of the stock replaced by CFLs in 2030 \\
\hline $\begin{array}{l}\text { Fluorescent } \\
\text { Lamp }\end{array}$ & $\begin{array}{l}\text { AUS+JPN+ } \\
\text { KOR+CAN } \\
\text { +USA } \\
\text { Other }\end{array}$ & $\begin{array}{l}\text { Watts } \\
\text { Watts }\end{array}$ & $\begin{array}{l}40 \\
46\end{array}$ & $\begin{array}{l}36 \\
36\end{array}$ & $\begin{array}{l}\text { Target Efficiency corresponds to Electronic } \\
\text { Ballasts }\end{array}$ \\
\hline Refrigeration & $\begin{array}{l}\text { AUS } \\
\text { JPN } \\
\text { KOR } \\
\text { CAN+USA } \\
\text { CHN }\end{array}$ & $\begin{array}{l}\text { kWh/year } \\
\text { kWh/year } \\
\text { kWh/year } \\
\text { kWh/year } \\
\text { kWh/year }\end{array}$ & $\begin{array}{l}562 \\
535 \\
536 \\
562 \\
489\end{array}$ & $\begin{array}{l}498 \\
413 \\
487 \\
498 \\
413\end{array}$ & $\begin{array}{l}\text { Target Efficiency based on analysis of most } \\
\text { cost effective level (minimum Life Cycle } \\
\text { Cost), from U.S. analysis ( } 437 \mathrm{kWh} / \mathrm{y} \text { for TF } \\
606 \mathrm{~L} \text { AV). Other country targets calculated } \\
\text { according to average adjusted volume }\end{array}$ \\
\hline
\end{tabular}




\begin{tabular}{|c|c|c|c|c|c|}
\hline & IND & kWh/year & 548 & 338 & \\
\hline \multirow{2}{*}{ Oven } & \multirow{2}{*}{$\begin{array}{l}\text { AUS+JPN+ } \\
\text { KOR } \\
\text { CAN+USA }\end{array}$} & \multirow{2}{*}{$\begin{array}{l}\text { kWh/year } \\
\text { kWh/year }\end{array}$} & \multirow{2}{*}{132} & \multirow{2}{*}{$\begin{array}{l}132 \\
167\end{array}$} & $\begin{array}{l}\text { Ovens are not considered as a significant } \\
\text { source of efficiency improvement }\end{array}$ \\
\hline & & & & & $\begin{array}{l}\text { Ovens are not considered as a significant } \\
\text { source of efficiency improvement }\end{array}$ \\
\hline Standby & All & $\begin{array}{l}\text { Watts/Devic } \\
\mathrm{e}\end{array}$ & 5 & 1 & $1 \mathrm{~W}$ standby found to be cost effective \\
\hline \multirow{5}{*}{$\begin{array}{l}\text { Washing } \\
\text { Machine }\end{array}$} & AUS & kWh/year & & 119 & European Label Level A \\
\hline & JPN & kWh/year & 96 & 14 & $\begin{array}{l}\text { New High Efficiency washing machine } \\
\text { ( } 54 \text { Wh/cycle) becomes mandatory by } 2010 \\
\text { (assumes } 250 \text { cycles per year) }\end{array}$ \\
\hline & CAN+USA & $\begin{array}{l}\text { kWh/year } \\
\text { kWh/year }\end{array}$ & $\begin{array}{r}96 \\
194\end{array}$ & 14 & $\begin{array}{l}\text { No further efficiency improvement after } \\
2007 \text { standard set at } 775 \mathrm{Wh} / \text { cycle }\end{array}$ \\
\hline & CHN & kWh/year & 12 & 6 & $\begin{array}{l}\text { Based on } 32 \mathrm{Wh} / \mathrm{kg} / \mathrm{cycle} \text { for the baseline } \\
\text { and } 17 \mathrm{Wh} / \mathrm{kg} / \mathrm{cycle} \text { for the efficiency } \\
\text { scenario (current endorsement label), } \\
\text { assumes } 2.5 \mathrm{~kg} / \mathrm{cycle} \text { and } 250 \text { cycles/year }\end{array}$ \\
\hline & IND & kWh/year & 190 & 102 & $\begin{array}{l}\text { Based on India Market consideration (semi } \\
\text { automatic machines versus horizontal axis) }\end{array}$ \\
\hline Television & All & $\begin{array}{l}\text { Efficiency } \\
\text { Rating }\end{array}$ & $100 \%$ & $135 \%$ & $\begin{array}{l}\text { 34\% improvement on LCD, 36\% on Plasma } \\
\text { TVs by } 2010\end{array}$ \\
\hline \multirow{6}{*}{ Space Cooling } & AUS & & 3.2 & 3.2 & $\begin{array}{l}\text { Most Cost Effective level, based on } \\
\text { minimum lifecycle cost found at } 3.2 \text { EER }\end{array}$ \\
\hline & JPN & EER & 4.0 & 4.0 & No further Improvement \\
\hline & KOR & EER & 3.2 & 3.2 & $\begin{array}{l}\text { Most Cost Effective level, based on } \\
\text { minimum lifecycle cost found at } 3.2 \text { EER }\end{array}$ \\
\hline & \multirow{3}{*}{$\begin{array}{l}\text { CAN+USA } \\
\text { IND } \\
\text { CHN }\end{array}$} & \multirow{3}{*}{$\begin{array}{l}\text { EER } \\
\text { EER } \\
\text { EER }\end{array}$} & \multirow{3}{*}{$\begin{array}{l}3.4 \\
2.3 \\
2.6\end{array}$} & \multirow{3}{*}{$\begin{array}{l}3.4 \\
3.2 \\
3.2\end{array}$} & $\begin{array}{l}\text { Improvement of Central AC not cost } \\
\text { effective }\end{array}$ \\
\hline & & & & & Most Cost Effective level, based on \\
\hline & & & & & minimum lifecycle cost found at 3.2 EER \\
\hline \multirow{4}{*}{ Water Heating } & $\begin{array}{l}\text { AUS+JPN+ } \\
\text { KOR }\end{array}$ & $\begin{array}{l}\text { Efficiency } \\
\text { Factor }\end{array}$ & 0.83 & 0.92 & \multirow{4}{*}{$\begin{array}{l}\text { Heat Pump Water Heaters not cost } \\
\text { effective till 2020. Use Current U.S. } \\
\text { Standards for Target for All Regions }\end{array}$} \\
\hline & CAN+USA & $\begin{array}{l}\text { Efficiency } \\
\text { Factor }\end{array}$ & 0.92 & 0.92 & \\
\hline & IND & $\begin{array}{l}\text { Efficiency } \\
\text { Factor }\end{array}$ & 0.76 & 0.92 & \\
\hline & CHN & $\begin{array}{l}\text { Efficiency } \\
\text { Factor }\end{array}$ & 0.76 & 0.92 & \\
\hline \multirow{3}{*}{ Fans } & $\mathrm{CHN}$ & kWh/year & 10 & 6 & \\
\hline & IND & kWh/year & 150 & 92 & Energy Star Level found to be Cost Effective \\
\hline & Other & $\mathrm{kWh} /$ year & 88 & 54 & \\
\hline \multirow{3}{*}{ Space Heating } & $\begin{array}{l}\text { AUS }+\mathrm{JPN}+ \\
\mathrm{KOR}\end{array}$ & $\begin{array}{l}\text { Relative } \\
\text { Efficiency } \\
\text { Rating }\end{array}$ & 1.5 & 2.0 & $\begin{array}{l}\text { Assume Heat Pump Efficiency meets RAC } \\
\text { Efficiency - } 50 \% \text { of electric SH }\end{array}$ \\
\hline & \multirow[t]{2}{*}{ CAN+USA } & \multirow{2}{*}{$\begin{array}{l}\text { Relative } \\
\text { Efficiency } \\
\text { Rating } \\
\text { Relative } \\
\text { Efficiency } \\
\text { Rating } \\
\end{array}$} & 1.5 & 1.5 & $\begin{array}{l}\text { Improvement of Central AC not cost } \\
\text { effective }\end{array}$ \\
\hline & & & 1.0 & 2.0 & $\begin{array}{l}\text { Assume Heat Pump Efficiency meets RAC } \\
\text { Efficiency - } 50 \% \text { of electric SH }\end{array}$ \\
\hline
\end{tabular}


Table 3. Efficiency Assumptions for Cost-Effective Targets of DSM Programs Commercial Buildings

\begin{tabular}{|c|c|c|c|c|c|}
\hline Enduse & Region & Units & $\begin{array}{l}\text { Base Case } \\
\text { Average } \\
\text { Efficiency }\end{array}$ & $\begin{array}{c}2010 \\
\text { Cost } \\
\text { Effective } \\
\text { Target } \\
\end{array}$ & Assumptions \\
\hline \multirow{7}{*}{ Lighting } & AUS & Relative Index & 1.05 & 1.27 & \multirow{7}{*}{$\begin{array}{l}\text { Efficiency Index calculated according to } \\
\text { technology Mix. Efficiency Improvement from } \\
\text { combination of Electronic Ballasts and High } \\
\text { Performance T8 Tube }\end{array}$} \\
\hline & JPN & Relative Index & 1.05 & 1.27 & \\
\hline & KOR & Relative Index & 1.05 & 1.27 & \\
\hline & CAN & Relative Index & 0.97 & 1.31 & \\
\hline & USA & Relative Index & 0.97 & 1.31 & \\
\hline & $\mathrm{CHN}$ & Relative Index & 0.81 & 1.27 & \\
\hline & IND & Relative Index & 0.81 & 1.29 & \\
\hline \multirow{7}{*}{$\begin{array}{c}\text { Space } \\
\text { Cooling }\end{array}$} & AUS & Relative Index & 1.05 & 1.05 & \multirow{7}{*}{$\begin{array}{l}\text { Space Cooling efficiency based on weighted } \\
\text { average of Chillers, Package/Split (and Multi- } \\
\text { Split) and Room Air Conditioners. Chiller } \\
\text { Efficiency Improvements in China and India to } \\
\text { reach current European Baseline. Central AC } \\
\text { improvement according to cost-benefit analysis. } \\
\text { Room Air Conditioner according to residential } \\
\text { cost-benefit analysis }\end{array}$} \\
\hline & JPN & Relative Index & 1.62 & 1.62 & \\
\hline & KOR & Relative Index & 1.00 & 1.00 & \\
\hline & CAN & Relative Index & 1.05 & 1.05 & \\
\hline & USA & Relative Index & 1.18 & 1.31 & \\
\hline & $\mathrm{CHN}$ & Relative Index & 2.40 & 2.80 & \\
\hline & IND & Relative Index & 2.40 & 2.80 & \\
\hline Refrigeration & All & $\begin{array}{c}\% \\
\text { improvement }\end{array}$ & $0 \%$ & $34 \%$ & $\begin{array}{l}\text { U.S. cost-effective efficiency improvement } \\
\text { levels, weighted by market share (percent of } \\
\text { electricity consumption) for each equipment } \\
\text { type. }\end{array}$ \\
\hline Ventilation & All & $\begin{array}{c}\% \\
\text { improvement }\end{array}$ & $0 \%$ & $10 \%$ & $\begin{array}{l}10 \% \text { represents an easily achievable target, and } \\
20 \% \text { is the maximum cost-effective efficiency } \\
\text { level }\end{array}$ \\
\hline $\begin{array}{l}\text { Office } \\
\text { Equipment }\end{array}$ & All & $\begin{array}{c}\text { Standby } \\
\text { Watts/Device }\end{array}$ & 5 & 1 & $\begin{array}{l}\text { Low Standby Power (1 Watt) Found to be cost } \\
\text { effective for a range of electronic products in the } \\
\text { U.S. }\end{array}$ \\
\hline \multirow{7}{*}{$\begin{array}{l}\text { Space } \\
\text { Heating }\end{array}$} & AUS & \% Efficiency & $100 \%$ & $100 \%$ & \multirow{5}{*}{$\begin{array}{l}\text { Electric Space Heating Efficiency improvement } \\
\text { from cost effective improvement from Heat } \\
\text { Pumps Only. }\end{array}$} \\
\hline & JPN & \% Efficiency & $313 \%$ & $358 \%$ & \\
\hline & KOR & \% Efficiency & $100 \%$ & $100 \%$ & \\
\hline & CAN & \% Efficiency & $100 \%$ & $100 \%$ & \\
\hline & USA & \% Efficiency & $323 \%$ & $394 \%$ & \\
\hline & $\mathrm{CHN}$ & \% Efficiency & $100 \%$ & $100 \%$ & \multirow{2}{*}{$\begin{array}{l}\text { Assume dominated by Resistance Heating. No } \\
\text { Improvement }\end{array}$} \\
\hline & IND & \% Efficiency & $100 \%$ & $100 \%$ & \\
\hline
\end{tabular}

\section{Results}

Once the unit efficiency levels are determined, total electricity demand, demand savings and mitigation is determined according to stock turnover calculation (Module 3 of BUENAS). Table 4 shows the electricity demand forecast, and the energy and $\mathrm{CO}_{2}$ emissions savings potential in 2030. 
Table 4. Electricity Demand Projections, Energy and Emission Savings Potential

\begin{tabular}{|c|c|c|c|c|c|c|c|c|c|}
\hline \multirow[t]{2}{*}{ Country } & \multicolumn{3}{|c|}{2030 Demand(TWh) } & \multicolumn{3}{|c|}{2030 Savings (TWh) } & \multicolumn{3}{|c|}{2030 Emissions Mitigation (MtCO2) } \\
\hline & Residential & Commercial & Total & Residential & Commercial & Total & Residential & Commercial & Total \\
\hline Australia & 91.5 & 97.3 & 188.8 & 10.4 & 9.6 & 20.0 & 5.7 & 5.2 & 10.9 \\
\hline Canada & 250.7 & 234.5 & 485.2 & 28.4 & 44.2 & 72.6 & 13.7 & 24.8 & 38.5 \\
\hline China & 1201.6 & 586.1 & 1787.7 & 301.2 & 288.8 & 590.0 & 263.2 & 276.4 & 539.6 \\
\hline India & 527.5 & 205.1 & 732.6 & 201.4 & 73.7 & 275.0 & 142.4 & 52.1 & 194.5 \\
\hline Japan & 475.8 & 456.6 & 932.4 & 80.5 & 57.1 & 137.6 & 42.9 & 30.3 & 73.2 \\
\hline Korea & 115.2 & 279.2 & 394.3 & 14.1 & 22.5 & 36.7 & 8.7 & 13.5 & 22.2 \\
\hline $\begin{array}{l}\text { United } \\
\text { States }\end{array}$ & 1729.1 & 1934.3 & 3663.4 & 320.9 & 258.1 & 579.0 & 152.0 & 131.9 & 283.8 \\
\hline Total & 4391.5 & 3793.0 & 8184.5 & 957.0 & 753.9 & 1710.9 & 628.5 & 534.1 & 1162.6 \\
\hline
\end{tabular}

Savings potential varies across countries, ranging from a total for both sectors of $38 \%$ in India to $10 \%$ in Korea (Table 5). However, in absolute terms, the largest savings potential is in China closely followed by the US, India and Japan (Table 4). Graphs for each country are available in Annex 8. The total savings potential is 1733 TWh or about $22 \%$ of the 2030 projected base case demand for electricity in the APP countries.

Table 4 also shows the carbon mitigation potential for both sectors combined for each country. The total APP mitigation potential in 2030 is $1.2 \mathrm{GtCO}$. It ranges from 540 $\mathrm{MtCO}_{2}$ in China to 284 in US and 194 in India. Although the electricity savings potential is the same in China and the US, the carbon benefit is much higher in China due to its higher reliance on coal for electricity generation.

Table 5. Potential savings (\% of reference case), 2030

\begin{tabular}{|c|c|c|c|}
\hline Country & Residential & Commercial & Total \\
\hline Australia & $11 \%$ & $10 \%$ & $11 \%$ \\
\hline Canada & $11 \%$ & $19 \%$ & $15 \%$ \\
\hline China & $25 \%$ & $49 \%$ & $33 \%$ \\
\hline India & $38 \%$ & $36 \%$ & $38 \%$ \\
\hline Japan & $17 \%$ & $12 \%$ & $15 \%$ \\
\hline Korea & $12 \%$ & $8 \%$ & $9 \%$ \\
\hline United States & $19 \%$ & $13 \%$ & $16 \%$ \\
\hline Total & $\mathbf{2 2 \%}$ & $\mathbf{2 0 \%}$ & $\mathbf{2 1 \%}$ \\
\hline
\end{tabular}

Electricity savings opportunities from equipment efficiency in buildings are dependent on several main factors. Absolute savings is dependent on total consumption, and therefore usage, which can differ substantially by country. Replacement of incandescent lamps with CFLs is a significant area for savings in most countries. Standby power is an important target product, as this area has yet to be systematically and comprehensively addressed by most efficiency programs.

For example, total electricity saving from space heating improvements is large in Canada, but virtually zero in India. In percentage terms, savings is highly dependent on efficiency baselines - countries with already high efficiency standards may have less room for improvement to get to the level of maximum cost-effective efficiency. Countries like China and India, which have a somewhat lower efficiency baseline but expect very high growth in energy consumption, have the greatest opportunity for savings (Tables 4 and 5). 
For countries with well-established standards programs, further potential for improvement in the residential sector is somewhat limited due to the high baseline. This is partially a result of our methodology, which does not assume significant equipment price reductions due to technological advances, some of which will be encouraged by standards or DSM programs. For example, savings from air conditioning is somewhat limited in both the residential and commercial sectors. Our recent analysis suggests that going beyond the recent standard for residential central air conditioning in the United States and Canada would not be cost effective - therefore, there are no further savings for this end use. Japanese and Korean efficiency levels for room air conditioners (which is used in both sectors) are higher than the maximum cost-effective efficiency, therefore we assume no further improvement in Korea, but do include additional improvements already planned by the Japanese Top Runner program. On the other hand, savings potential from space cooling is large in India, (especially in the commercial sector), where baseline efficiency is low.

Figure 7. APP Electricity Savings Potential from DSM Programs - Residential Sector

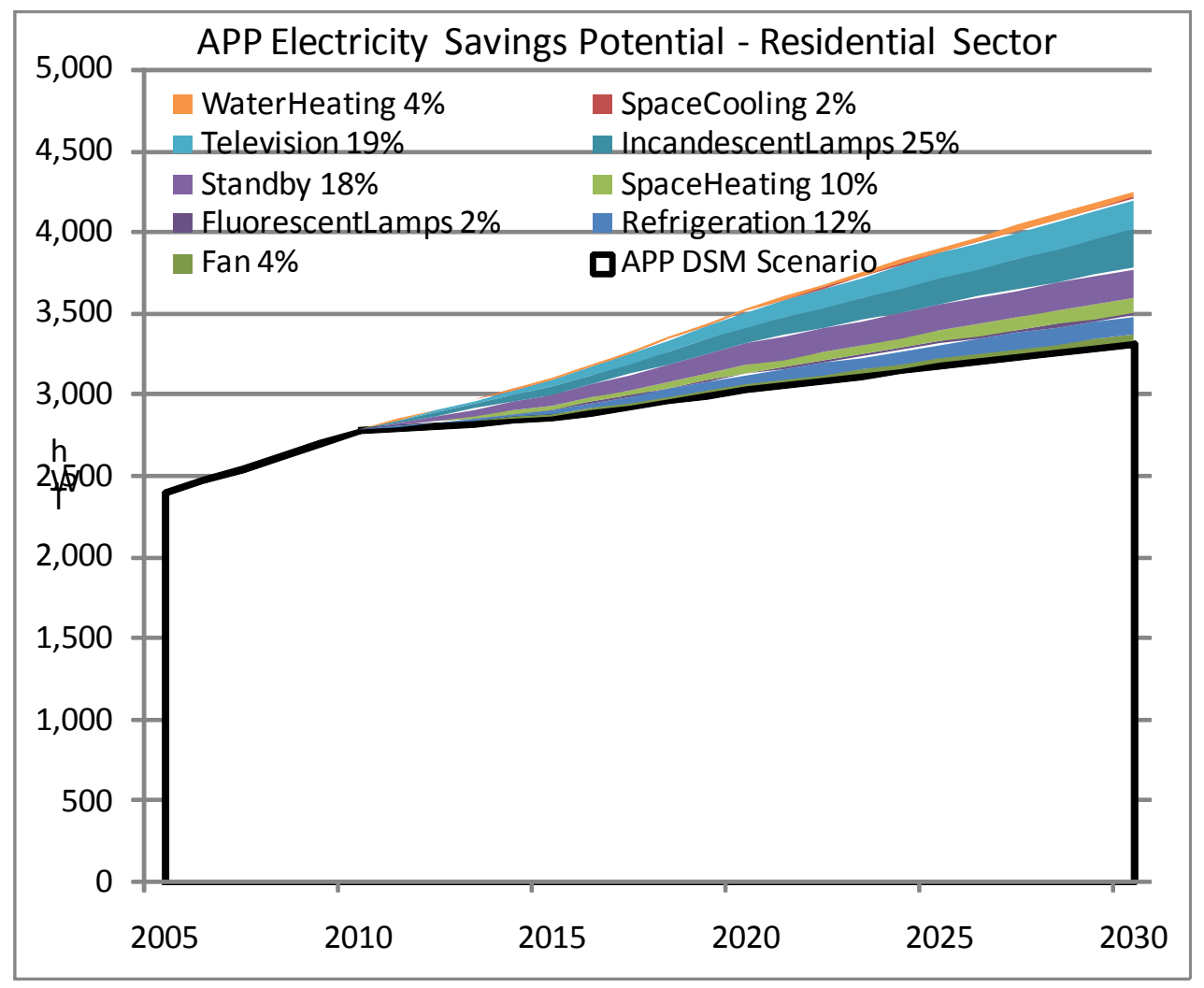


Figure 8. APP Electricity Savings Potential from DSM Programs - Commercial Sector

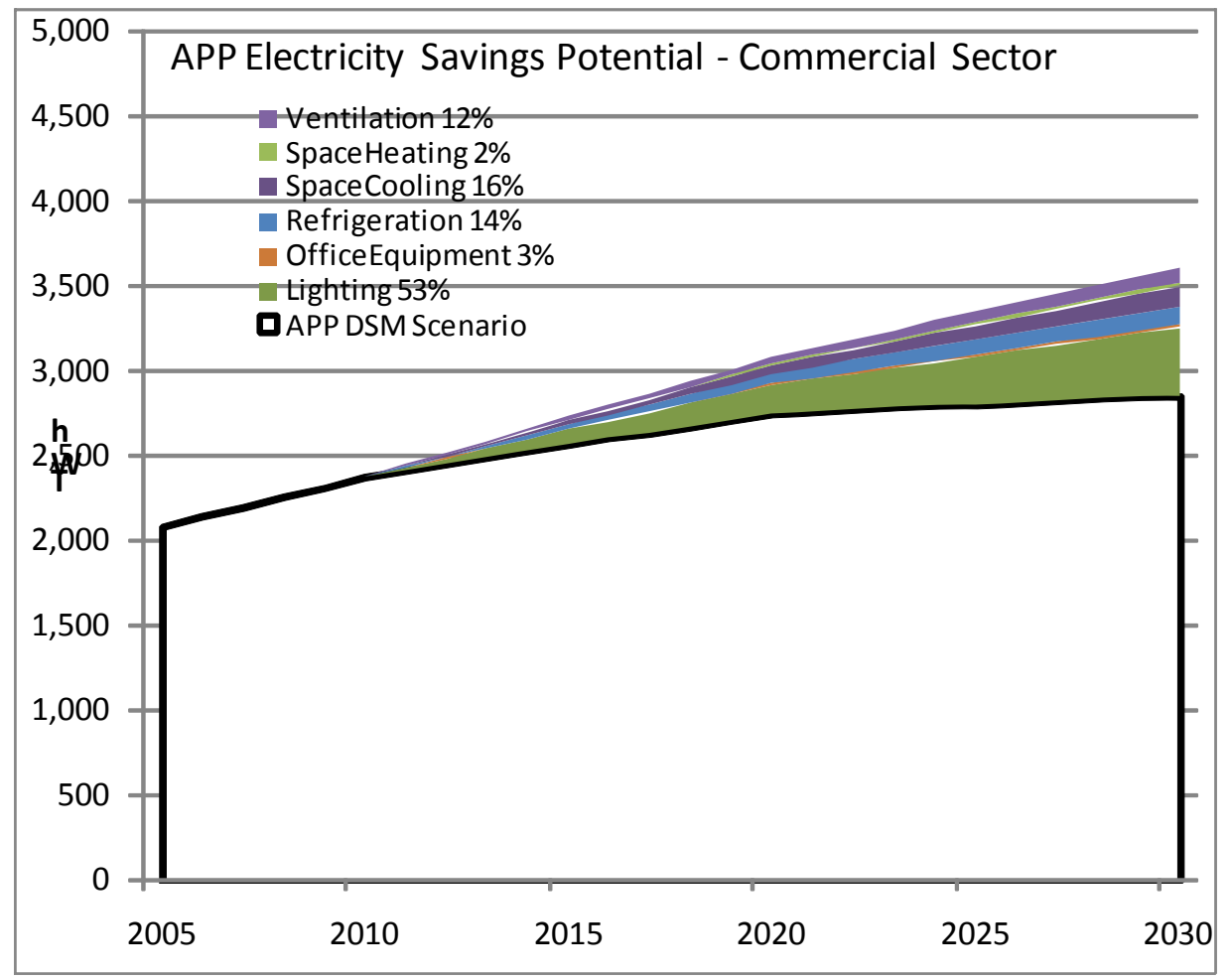

Figures 7 and 8 and Tables 6 and 7 show the overall savings potential for the APP region by end use. In the residential sector, replacement of incandescent lamps by CFL's shows by far the greatest potential in absolute (TWh) terms, although in relative terms, standby reduction is higher (assuming a reduction of $5 \mathrm{~W}$ to $1 \mathrm{~W}$ standby for all products).

Refrigerators, standby power and televisions all show a large overall potential savings by $2030^{10}$. In absolute terms, the savings potential is higher in the residential sector, where about 960 TWh could be saved in 2030. Commercial sector savings is only about threequarters of this. One reason for this is the large expected growth in the residential sectors in China and India, and the larger array of common residential end uses, like incandescent lights and refrigerators, that consume a great deal of electricity, but also offer large opportunity, in terms of per-unit efficiency improvement.

\footnotetext{
${ }^{10}$ Standby reduction may not be as high as estimated in countries where appliances are switched off externally when not in use.
} 
Table 6. Electricity End Use Savings in all APP countries by end use -

Residential Sector

\begin{tabular}{|l|c|c|c|c|c|c|}
\hline \multirow{2}{*}{\multicolumn{1}{|c|}{ End Use }} & \multicolumn{3}{|c|}{2020} & \multicolumn{3}{c|}{2030} \\
\cline { 2 - 7 } & Demand & Savings & \% Savings & Demand & Savings & $\%$ Savings \\
\cline { 2 - 7 } & TWh & TWh & $\%$ & TWh & TWh & $\%$ \\
\hline Fan & 86 & 25 & $29 \%$ & 104 & 40 & $39 \%$ \\
Fluorescent Lamps & 103 & 10 & $9 \%$ & 133 & 22 & $17 \%$ \\
Incandescent Lamps & 485 & 100 & $21 \%$ & 615 & 242 & $39 \%$ \\
Laundry & 77 & 16 & $21 \%$ & 98 & 30 & $30 \%$ \\
Refrigeration & 477 & 57 & $12 \%$ & 625 & 116 & $19 \%$ \\
Space Cooling & 469 & 7 & $2 \%$ & 559 & 16 & $3 \%$ \\
Space Heating & 474 & 48 & $10 \%$ & 555 & 96 & $17 \%$ \\
Standby & 176 & 136 & $77 \%$ & 221 & 177 & $80 \%$ \\
Television & 355 & 94 & $26 \%$ & 512 & 181 & $35 \%$ \\
Water Heating & 643 & 18 & $3 \%$ & 774 & 36 & $5 \%$ \\
\hline All End uses & 3345 & 509 & $15 \%$ & 4195 & 957 & $23 \%$ \\
\hline
\end{tabular}

Lighting is also the largest single potential contributor to savings in the commercial sector, with over half of overall savings arising from this end use. Both refrigeration and space cooling show a very significant potential savings from DSM programs.

Table 7. Electricity End Use Savings in all APP countries by end use -

Commercial Sector

\begin{tabular}{|l|c|c|c|c|c|c|}
\hline \multirow{3}{*}{\multicolumn{1}{|c|}{ Enduse }} & \multicolumn{3}{|c|}{2020} & \multicolumn{3}{c|}{2030} \\
\cline { 2 - 7 } & Demand & Savings & \% Savings & Demand & Savings & \% Savings \\
\cline { 2 - 7 } & TWh & TWh & $\%$ & TWh & TWh & $\%$ \\
\hline Lighting & 771 & 170 & $22 \%$ & 977 & 398 & $41 \%$ \\
Office Equipment & 277 & 10 & $4 \%$ & 351 & 22 & $6 \%$ \\
Refrigeration & 249 & 60 & $24 \%$ & 315 & 107 & $34 \%$ \\
Space Cooling & 557 & 48 & $9 \%$ & 722 & 120 & $17 \%$ \\
Space Heating & 317 & 9 & $3 \%$ & 396 & 17 & $4 \%$ \\
Ventilation & 406 & 40 & $10 \%$ & 514 & 90 & $17 \%$ \\
\hline All End uses & 2900 & 336 & $12 \%$ & 3636 & 754 & $21 \%$ \\
\hline
\end{tabular}

Demand totals in Table 6 and 7 are slightly lower than those in Table 4, because they do not include some end uses implicitly covered by the top down model, and because end uses for which savings estimates are not modeled are omitted.

\section{Summary and Conclusion}

There are many different types of policies including DSM programs that APP and other countries are using to manage the growth of electricity demand. DSM programs use financial incentives to increase the penetration of efficiency measures and serve as a costeffective alternative to building new power supply. In this paper, we estimate the DSM economic potential from a consumer perspective for 2010, 2020 and 2030 for the seven APP countries. The demand-side energy efficiency economic potential is based on our estimated cost of conserved energy, which is compared with residential and commercial 
tariffs for the APP countries. Measures with lower CCE compared to the tariffs are included in the potential estimation.

Overall, the savings potential is estimated to be 1.7 thousand TWh or $21 \%$ of the 2030 projected base case electricity demand. Electricity savings potential ranges from a high of $38 \%$ in India to a low of $9 \%$ in Korea for the two sectors. Lighting, fans, and TV sets and lighting and refrigeration are the largest contributors to residential and commercial electricity savings respectively.

The emissions reductions in that year amount to $1.2 \mathrm{GtCO}_{2}$. Because of its heavy use of coal for electricity generation, emissions reductions from China constitute about $46 \%$ of the 2030 APP emissions reductions although its electricity savings are about a third of the total. Chinese savings potential is particularly large in the commercial sector, since, while China has a mature efficiency standards program, standards have focused on the residential sector, and are only now being extended to commercial equipment. US and India 2030 emissions reductions are 284 (24\%) and 195 (17\%) $\mathrm{MtCO}_{2}$ respectively of the total APP savings.

The estimates suggest that more than a third of India's emissions and about a quarter of China and Japan's emissions in the two sectors could be reduced through demand-side energy efficiency programs.

The above potential may be captured through DSM financial incentives or through a tightening or setting of new standards and labels. Other forms of measures exist, such as in some states in Australia, where greenhouse gas (GHG) emissions associated with the production of electricity are capped and utilities are required to meet the target partially or entirely through energy efficiency activities. Another example, is the newly created “carbon cashback” initiative in Korea that awards carbon points to consumers of high efficiency electronics and appliances.

All these policies have a goal to not only increase energy efficient product penetration by overcoming the higher first cost of energy efficient products but also to modify customer behavior toward accepting energy efficient product by opening their mind to the benefit of buying such products.

\section{Future Work}

While the above estimates are based on detailed end-use data, it is worth keeping in mind that some limitations exist in this exercise.

First, we did not take into account all the additional potential that exists from building shell improvement and have focused mainly on equipment efficiency improvement. Hence, building codes as well as potential DSM programs targeting building shell improvement are not included in this analysis.

Second, the effort was limited to buildings only and does not include industrial and agricultural sector options that are important in China and India for instance.

Third, the analysis focuses on two scenarios a base case and a cost-effective potentials case. Other policy measures such as standards would reduce the estimated DSM potential while a carbon price program would increase the potential. 
Fourth, we used a study done for the US to assess the cost effectiveness of energy efficiency improvement for each individual country. Future work should focus on gathering and/or developing similar data for each country.

Fifth, the above estimation was done from a consumer perspective. It is important to do the exercise from a societal perspective using discount rates specific to each country.

Finally, since the analysis focuses on each APP country separately, it would be useful to engage experts from each country so that the knowledge, literature and reference material is fully captured in the analysis. 


\section{References}

Australia Government, 2009a. "Phase-out of inefficient incandescent light bulbs", information from the Australian Government Department of the Environment, Water, Heritage and the Arts website as retrieved on March 21, 2009.

http://www.environment.gov.au/settlements/energyefficiency/lighting/faq-phaseout.html

Australia Government, 2009b. “ Green Loans”, information from the Australian Government Department of the Environment, Water, Heritage and the Arts website as retrieved on January 26, 2009, http://www.environment.gov.au/greenloans/news/update.html\#overview

Blumstein, C., Goldman, C., Barbose, G., 2005. "Who should administer energy efficiency programs?” Energy Policy 33, 1053-1067, May 2005.

California Energy Commission, 2005. “Implementing California's Loading Order for Electricity Resources”, Staff Report, CEC-400-2005-043, July 2005

http://www.energy.ca.gov/2005publications/CEC-400-2005-043/CEC-400-2005043.PDF

Canada Office for Energy Efficiency, 2008. “Energy Use Data Handbook Tables”, Natural Resources Canada, 2008. http://oee.nrcan.gc.ca/english/index.cfm?attr=0

CLASP, 2009

Crossley, 2004. “International Developments in Electricity Demand Management Lessons for Australia", presentation to EESA Conference "Electricity 2004...The Next 80 Years”, Sydney, 12 August 2004

Eldridge Maggie, Max Neubauer, Dan York, Shruti Vaidyanathan, Anna Chittum, and Steven Nadel, 2008. "2008 State Energy Efficiency Scorecard”, American Council for an Energy Efficient economy (ACEEE), ACEEE Report number E068, http://www.aceee.org/pubs/e086.htm

Energy Efficiency Working Group (EEWG), 2008. "Institutional and Regulatory Barriers to Utility Demand-Side Management in Canada”, EEWG Issue Paper, Issue Paper Five, Energy Efficiency Working Group, Energy Sector Sustainability Table, November 2008. http://www.sst.gc.ca/Publications/Energy Efficiency Working Group-WSED717E3F0_En.htm

Energy Foundation (EF), 2006. “China Electric Utilities Program: Strategy and Project Descriptions”. http://www.efchina.org/FReports.do?act=detail\&id=158

Energy Rating, 2009. energy rating website, last consulted on January 26, 2009. http://www.energyrating.gov.au/

Fridley, David; Aden, Nathaniel, eds. China Energy Databook, Version 7. Lawrence Berkeley National Laboratory, Report LBNL-1135E. 2008.Government of India, 2008, 
“National Action Plan on Climate Change”, Prime Minister's Council on Climate Change, 2008. http://pmindia.nic.in/Pg01-52.pdf

Hu Zhaoguang, Moskovitz David and Zhao Jianping. "Restructured Power Industry: How Regulation and Policy Can Deliver Demand-Side Management Benefits to a Growing Economy and a Changing Power System”, Energy Sector Management Assistance Program (ESMAP), December 2005, http://www.raponline.org/Pubs/China/Dec05ChinaDSM.pdf

Independent Pricing and Regulatory Tribunal (IPART), 2008. “Compliance and Operation of the NSW Greenhouse Gas Reduction Scheme during 2007”, Report to Minister, New South Wales, July 2008.

India Ministry of Finance (MOF), 2008. “Economic Survey 2007-2008”, http://indiabudget.nic.in

International Energy Agency (IEA), 2009. “Energy Prices \& Taxes (4Q2008): End-Use Prices”, online database, OECD/IEA 2009,

International Energy Agency (IEA), 2008. “Energy Efficiency Policies and Measures database”, OECD/IEA 2008, http://www.iea.org/textbase/pm/index_effi.asp

Kemco, 2009. ”Financial Assistance”, information from Kemco website as on February 2009. http://www.kemco.or.kr/web/kcms/main/kcms.asp?c=PAGEML000000718

Kim Hyung-Taek, 2008. "Market Transformation: Good Practices in Korea” presentation to the Asian Pacific Partnership (APP) buildings and appliances task force workshop on Market Transformation held in Tokyo, Japan on 31 January - 1 February, 2008.

http://www.asiapacificpartnership.org/pdf/BATF/2nd_market_transformation/Korea_AP P\%202ndMTworkshop.pdf

McNeil, M. A., V. E. Letschert and S. de la Rue du Can (2008). “Global Potential of Energy Efficiency Standards and Labeling Programs”, LBNL for METI. Available at http://ies.lbl.gov/gedc.

Ministerial Council on Energy (MCE), Communiqué, Adelaide, 27 August 2004. http://www.mce.gov.au/assets/documents/mceinternet/8MCECommunique27August2004 2004082714194520041124163539.pdf

Moskovitz David, “Meeting China's Energy Efficiency Goals Means China Needs to Start Building Efficiency Power Plants (EPP)”, November 2005. http://www.raponline.org/Pubs/China/ChinaDailyEPP.pdf

Natural Resources Canada (NRCAN), 2009, “Energy-Efficiency Regulations” information from the Natural Resources Canada. http://www.nrcanrncan.gc.ca/media/newcom/2007/200704b-eng.php\#tphp 
New South Wales Government, 2008. "NSW Energy Efficiency Trading Scheme Discussion Paper" NSW Department of Environment and Climate Change and NSW Department of Water and Energy, July 2008.

http://www.dwe.nsw.gov.au/energy/pdf/sustain_neet_discussion_paper.pdf

Pandian G., 2008. "IndiaProgress of Standards and Labeling programme in India”, Bureau of Energy Efficiency (BEE) presentation to the International Conference on Standby Power, $22^{\text {nd }}$ and $3^{\text {rd }}$ April 2008, New Delhi, India. New

Phadke A., Sathaye J. and Padmanabhan S. 2005. Economic benefits of reducing Maharashtra's electricity shortage through end-use efficiency improvement. LBNL Report. 57053

Prayas Energy Group, 2005. "Demand-Side Management (DSM) in the Electricity Sector: Urgent Need for Regulatory Action and Utility-Driven Programs”, Prayas Energy Group (Pune) for Climate Change \& Energy Programme World Wide Fund for Nature, India, New Delhi, February - 2005, http://prayaspune.org/peg/publications/dsm_electricity_sector_057A01.pdf

Queensland Government, 2009. "Smart Energy Policy”. information from the Queensland Government of Australia, Department of Mine and Energy website as retrieved on January 26, 2009, http://www.dme.qld.gov.au/Energy/energy_policy.cfm

Rosenquist, G., M. McNeil, M. Iyer, S. Meyers and J. McMahon (2006). "Energy efficiency standards for equipment: Additional opportunities in the residential and commercial sectors." Energy Policy 34(17).

Sathaye J., S. de la Rue du Can, S. Kumar, M. Iyer, C. Galitsky, A. Phadke, M. McNeill, L. Price, R. Bharvirkar and S. Padmanabhan (2006). Implementing End-use Efficiency Improvements in India: Drawing from Experience in the US and Other Countries. LBNL Report -- 60035

Shenoy, Bhamy, and Gülen, Gürcan, 2007, Electricity and natural gas sectors in Korea: a synthetical overview and recent developments: KIET Industrial Economic Review, v. 12, no. 2, p. 27-45

Singh Anoop, 2006. "Power sector reform in India: current issues and prospects", Energy Policy, Volume 34, Issue 16, November 2006, Pages 2480-2490

Singh Daljit, Girish Sant and Ravindra Kadam, 2007. "Review of Nashik Pilot CFL Program of Maharashtra State Electricity Distribution Co Ltd.", Prayas Energy Group, Pune, December 2007. http://prayaspune.org/peg/publications/review_of_nashik_pilot_CFL_DSM_program_of MSEDCL_092A01.pdf

The Energy and Ressource Institute (TERI), 2008. "TEDDY: TERI's energy data directory and yearbook 2007”, New Delhi: Tata Energy Research Institute, 2008. www.teriin.org 
U. S. Energy Information Administration (US EIA), 2009a. "Status of Electricity Restructuring by State”, information from the US EIA website as of January 2009, Washington, DC: EIA.

http://www.eia.doe.gov/cneaf/electricity/page/restructuring/restructure_elect.html

U. S. Energy Information Administration (US EIA), 2009b. “Electric Power Industry 2007: Year in Review", Washington, DC: EIA.

http://www.eia.doe.gov/cneaf/electricity/epa/epa_sum.html

U. S. Energy Information Administration (US EIA), 2007. “International Energy Outlook 2007”. Washington, DC: EIA., http://www.eia.doe.gov/oiaf/ieo/

U.S. Environmental Protection Agency (US EPA), 2007. "Aligning Utility Incentives with Investment in Energy Efficiency”, National Action Plan for Energy Efficiency, prepared by Val R. Jensen, ICF International. www.epa.gov/eeactionplan

Vine E., C.H. Rheeb, and K.D. Leeb, 2006. "Measurement and evaluation of energy efficiency programs: California and South Korea”, Energy 31 (2006) 1100-1113.

Zhou, 2008. "Status of China’s Energy Efficiency Standards and Labels for Appliances and International Collaboration”, Lawrence Berkeley National Laboratory. Berkeley, CA. Report No. 251E, March 2008, http://china.lbl.gov/files/LBNL\%20251E.\%20Status\%20of\%20China\%27s\%20Energy\% 20Efficiency\%20Standards\%20and\%20Lables.\%20Mar2008.pdf 
Annex 1. Australia MEPS Programs

\begin{tabular}{|l|l|l|}
\hline Equipment & Starting in & Revision \\
\hline Refrigerators and Freezers & October 1999 & January 2005 \\
\hline Mains Pressure Electric Storage Water Heaters & October 1999 & \\
\hline $\begin{array}{l}\text { Small Mains Pressure Electric Storage Water } \\
\text { Heaters (<80L) and Low Pressure and Heat } \\
\text { Exchanger Types }\end{array}$ & October 2005 & \\
\hline Three Phase Electric Motors (0.73kw To <185kw) & October 2001 & April 2006 \\
\hline Single Phase Air Conditioners & October 2004 & $\begin{array}{l}\text { April 2006 and } 2007 \text { and } \\
2008\end{array}$ \\
\hline $\begin{array}{l}\text { Three Phase Air Conditioners up to 65kw Cooling } \\
\text { Capacity }\end{array}$ & October 2001 & October 2007 \\
\hline Ballasts for Linear Fluorescent Lamps & March 2003 & \\
\hline $\begin{array}{l}\text { Linear Fluorescent Lamps - from 550mm to } \\
\text { 1500mm inclusive with a Nominal Lamp Power } \\
>16 W\end{array}$ & & \\
\hline $\begin{array}{l}\text { Distribution Transformers - 11kv and 22kv with a } \\
\text { rating from 10ka to 2.5MVA }\end{array}$ & October 2004 & \\
\hline $\begin{array}{l}\text { Commercial Refrigeration (self contained and } \\
\text { remote systems) }\end{array}$ & October 2004 & \\
\hline Incandescent Lamps & November 2008 & \\
\hline Compact Fluorescent Lamps & November 2008 & \\
\hline external power supplies & December 2008 & \\
\hline Set top boxes & December 2008 & \\
\hline Commercial Building Chillers & approved for July 2009 & \\
\hline Close Control Air Conditioners & proposed for July 2009 & \\
\hline $\begin{array}{l}\text { transformers and electronic step-down converters } \\
\text { for ELV lamps }\end{array}$ & proposed for October \\
2010 & \\
\hline
\end{tabular}

Source: Energy Rating, 2009.

http://www.energyrating.gov.au/ 


\section{Annex 2. China MEPS and Label Programs}

\section{Minimum Efficiency Standards}

Domestic refrigerators/freezers ${ }^{*}$

Room air conditioners*

Clothes washers

Electric irons

Automatic rice cookers

Televisions

Radio receivers and recorders

Electric fans

Fluorescent lamp ballasts

Small electric motors

Compact fluorescent lamps

Linear fluorescent lamps

HPS lamps

HPS lamp ballasts

Instantaneous gas water Heaters

External power supplies

Commercial packaged AC

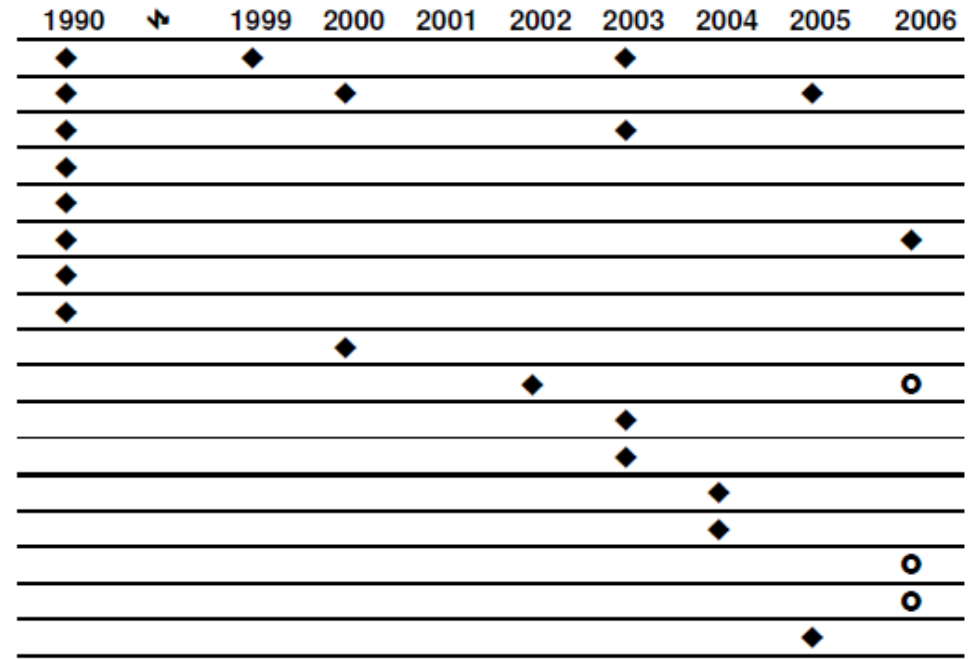

\section{Endorsement Labeling}

Domestic refrigerators/freezers *

Room air conditioners*

Fluorescent lamp ballasts

Automatic rice cookers

Hot water bottle

Small electric motors

Microwave ovens

Electric water heaters

Televisions

Compact Fluorescent lamps

Linear Fluorescent lamps

Clothes washers

Printers

Computers

Monitors

Fax machines

DVD players

Copiers

External power supplies

Set-Top-Box

\section{o}

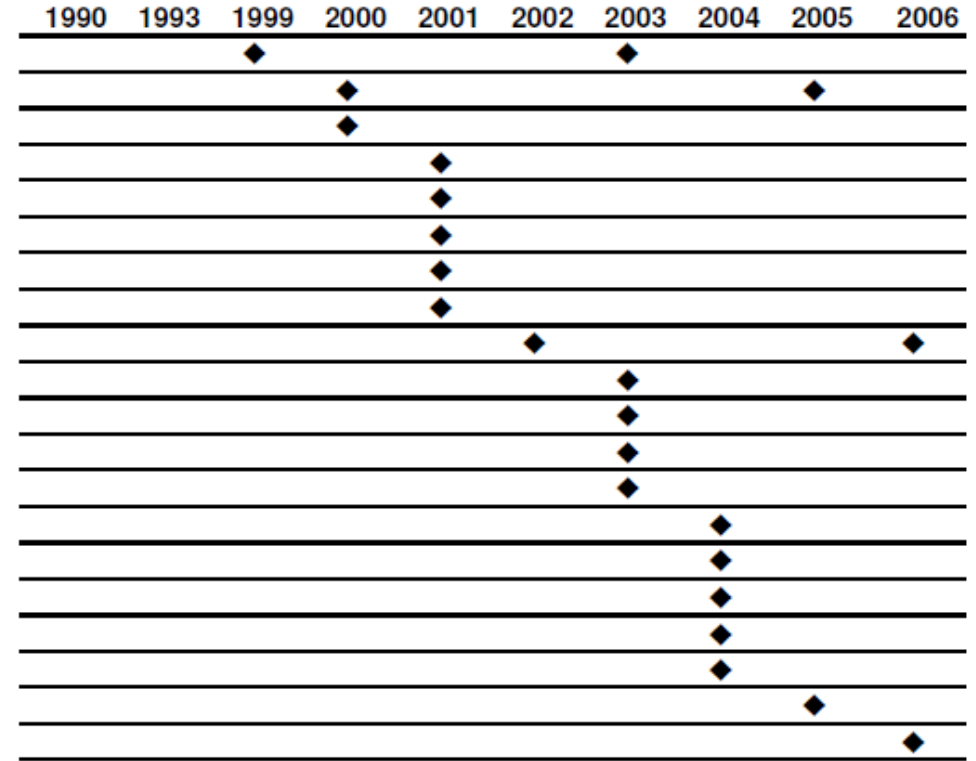

Implemention of standard/label or of standard/label revision

Currently under revision, development, or awaiting implementation

*Products subject to mandatory energy information labeling.

Source: Zhou, 2008 
Annex 3. Labels in India

\begin{tabular}{|l|l|l|l|}
\hline Product & Detail & $\begin{array}{l}\text { Type of } \\
\text { Label }\end{array}$ & Year* \\
\hline Refrigerator & $\begin{array}{l}\text { Domestic Refrigerator - Frost Free \& } \\
\text { Direct Cool }\end{array}$ & Mandatory & 2006 \\
\hline Fluorescent Lamps & $\begin{array}{l}\text { Tubular Fluorescent Lamps - 1200mm } \\
\text { for wattages up to 40K }\end{array}$ & $\begin{array}{l}\text { Voluntary } \\
\text { Label }\end{array}$ & 2006 \\
\hline RACs (Split) & $\begin{array}{l}\text { Room Air Conditioners - Single-phase } \\
\text { split \& unitary AC up to a rated cooling } \\
\text { capacity of 11kW }\end{array}$ & Mandatory & 2006 \\
\hline Transformers & $\begin{array}{l}\text { Distribution Transformer of ratings 16, } \\
\text { 25, 63, 100, 125, 200 kVA capacity }\end{array}$ & Mandatory & 2006 \\
\hline $\begin{array}{l}\text { Motors (3-phase } \\
\text { Induction) }\end{array}$ & $\begin{array}{l}\text { Induction Motor - 3-Phase Squirrel } \\
\text { Cage Induction }\end{array}$ & Voluntary & 2006 \\
\hline Ceiling fans & & Label & In progress \\
\hline $\begin{array}{l}\text { Compact } \\
\text { Fluorescent Lamps } \\
\text { (CFL) }\end{array}$ & & In progress \\
\hline Agricultural pump & & In progress \\
\hline LPG stove & & In progress \\
\hline Set Top Box & & In progress \\
\hline Television & & & In progs \\
\hline
\end{tabular}

* year the labeling program first became effective.

Source: CLASP, 2009 
Annex 4. MEPS in Korea

\begin{tabular}{|l|l|l|}
\hline Product Description & Year Implemented & Year Updated \\
\hline Refrigerators & 1992 & $1997,2001,2004$ \\
\hline Freezers & 2004 & \\
\hline Kimchi Refrigerators & 2004 & \\
\hline Air Conditioners & 1993 & $1997,2001,2004$ \\
\hline Washing Machines & 2002 & 2004,2007 \\
\hline Drum Washing Machines & 2006 & \\
\hline Dish Washers & 2002 & 2004,2007 \\
\hline Dish Driers & 2007 & \\
\hline Hot and Cold Water Dispensers & 2002 & \\
\hline Rice Cookers & 2004 & \\
\hline Vacuum Cleaners & 2004 & 2003 \\
\hline Electric Fans & 2006 & 1997,2003 \\
\hline Air Cleaners & 2008 & \\
\hline Incandescent Bulbs & 1992 & \\
\hline Fluorescent Lamps & 1992 & \\
\hline Ballasts for Fluorescent Lamp & 1994 & \\
\hline Compact Fluorescent Lamps & 2000 & \\
\hline Three Phase Electric Motor & 2008 & \\
\hline Domestic Gas Boilers & 2001 & \\
\hline
\end{tabular}

Source: Kim 2008. 


\section{Annex 5. Target Year and Effects of Top Runner Program, Japan}

\begin{tabular}{|c|c|c|}
\hline Equipment & Target year & $\begin{array}{l}\text { Expected energy conservation effects as of } \\
\text { the previous fiscal year of the target }\end{array}$ \\
\hline $\begin{array}{l}1 \text { Gasoline and diesel passenger } \\
\text { vehicles }\end{array}$ & FY2015 & Approx. 23.5\% compared to FY2004 \\
\hline Minicoaches & FY2015 & Approx. 7.2\% compared to FY2004 \\
\hline LPG passenger vehicles & FY2010 & Approx. $11.4 \%$ compared to FY2001 \\
\hline Trailer buses & FY2015 & Approx. $12.1 \%$ compared to FY2002 \\
\hline 2 Air-conditioners & FY2010 & Approx. 22.4\% compared to FY2004 \\
\hline 3 Fluorescent lights & FY2005 & Approx. $16.6 \%$ compared to FY1997 \\
\hline 4 LCD and plasma televisions & FY2010 & Approx. $15.0 \%$ compared to FY2005 \\
\hline 5 Video-cassette recorders & FY2003 & Approx. 58.7\% compared to FY1997 \\
\hline 6 Copy machines & FY2006 & Approx. 30\% compared to FY1997 \\
\hline 7 Computers & FY2007 & Approx. 83\% compared to FY2007 \\
\hline 8 Magnetic disk units & FY2007 & Approx. $71.0 \%$ compared to FY2001 \\
\hline 9 Small freight cars & FY2015 & Approx. 12.6\% compared to FY2004 \\
\hline Large freight cars & FY2015 & Approx. $12.2 \%$ compared to FY2002 \\
\hline \multirow[t]{2}{*}{10 Electric refrigerators } & FY2010 & Approx. 21\% compared to FY2005 \\
\hline & FY2010 & Approx. $1.4 \%$ compared to \\
\hline 11 and freezers & FY2000 & $\begin{array}{l}\text { for gas space heaters; approx. } 3.8 \% \text { for oil } \\
\text { space heaters }\end{array}$ \\
\hline 12 Space heaters & FY2006 & \\
\hline 13 Gas cooking appliances & FY2006 & Approx. $13.9 \%$ compared to FY2000 \\
\hline 14 Gas water heaters & FY2006 & Approx. 4.1\% compared to FY2000 \\
\hline 15 Oil water heaters & FY2006 & Approx. 3.5\% compared to FY2000 \\
\hline 16 Electric toilet seats & FY2012 & Approx. 9.7\% compared to FY2006 \\
\hline $\begin{array}{l}17 \text { Vending machines (also } \\
\text { introducing a paper pack and cup } \\
\text { system) }\end{array}$ & FY2012 & Approx. 33.9\% compared to FY2006 \\
\hline 18 Transformers & $\begin{array}{l}\text { FY2006: oil- } \\
\text { filled } \\
\text { transformers } \\
\text { FY2007: mold } \\
\text { transformers } \\
\end{array}$ & Approx. 30.3\% compared to FY1999 \\
\hline 19 Microwave ovens & FY2008 & Approx. 8.5\% compared to FY2004 \\
\hline 20 Electric rice cookers & FY2008 & Approx. $11.1 \%$ compared to FY2003 \\
\hline 21 DVD recorders & FY2010 & Approx. 20.5\% compared to FY2006 \\
\hline
\end{tabular}


Annex 6. U.S. Appliance Standards (as of September 2005)

\begin{tabular}{|c|c|c|}
\hline & Product Type & Effective Dates \\
\hline \multirow[t]{17}{*}{ Residential Products } & Clothes washers & $1988,1994,2004,2007$ \\
\hline & Clothes dryers & 1988, 1994 \\
\hline & Dishwashers & 1988,1994 \\
\hline & Refrigerators, freezers \& refrigerator-freezers & 1990, 1993, 2001 \\
\hline & Room air conditioners & 1990,2000 \\
\hline & Water heaters & 1990, 2004 \\
\hline & Central air conditioners & 1992 \\
\hline & Furnaces and boilers & 1992 \\
\hline & Ranges \& ovens & 1990 \\
\hline & Pool heaters & 1990 \\
\hline & Direct heating equipment & 1990 \\
\hline & Mobile home furnaces & 1990 \\
\hline & Medium Base Compact Fluorescent Lamps & 2006 \\
\hline & Dehumidifiers & 2007 \\
\hline & Torchieres & 2006 \\
\hline & Unit Heaters & 2009 \\
\hline & Ceiling Fans \& Ceiling Fan Light Kits & 2007 \\
\hline \multirow{19}{*}{$\begin{array}{l}\text { Commercial } \\
\text { Products }\end{array}$} & Fluorescent lamp ballasts & 1990, 2005, 2010 \\
\hline & $\begin{array}{l}\text { Small packaged air conditioning \& heating } \\
\text { equipment - air source }\end{array}$ & 1994, 2010 \\
\hline & $\begin{array}{l}\text { Small packaged air conditioning \& heating } \\
\text { equipment - water source }\end{array}$ & 1994, 2003 \\
\hline & Packaged terminal air conditioners and heat pumps & 1994 \\
\hline & Warm-air furnaces & 1994, 2003 \\
\hline & Package boilers & 1994 \\
\hline & Storage \& instantaneous water heaters & 1994, 2003 \\
\hline & Storage tanks & 1994, 2003 \\
\hline & $\begin{array}{l}\text { Large packaged air conditioning \& heating } \\
\text { equipment - air source }\end{array}$ & 1995, 2010 \\
\hline & $\begin{array}{l}\text { Large packaged air conditioning \& heating } \\
\text { equipment - air source }\end{array}$ & 1995, 2004 \\
\hline & Commercial Prerinse Spray Valves & 2006 \\
\hline & Distribution Transformers, Low Voltage Dry Type & 2007 \\
\hline & Illuminated Exit Signs & \multirow[t]{3}{*}{2006} \\
\hline & Pedestrian Modules & \\
\hline & Traffic Signal Modules & \\
\hline & Mercury Vapor Lamp Ballasts & 2008 \\
\hline & $\begin{array}{l}\text { Commercial refrigerators, freezers, and refrigerator- } \\
\text { freezers }\end{array}$ & 2010 \\
\hline & Automatic commercial ice makers & 2010 \\
\hline & Commercial clothes washers & 2007 \\
\hline \multirow{4}{*}{$\begin{array}{l}\text { Residential and } \\
\text { Commercial }\end{array}$} & Toilets & \multirow[t]{4}{*}{2004} \\
\hline & Faucets & \\
\hline & Showerheads & \\
\hline & Urinals & \\
\hline
\end{tabular}

Sources: National Appliance Energy Conservation Act of 1987; Energy Policy Act of 1992; Energy Policy Act of 2005; and DOE Final Rules from 1989 to 2001. 
Annex 7. Status of Electricity Restructuring by State in the US

\begin{tabular}{|c|c|c|c|}
\hline US States & Restructuration & US States & Restructuration \\
\hline Alabama & Not Active & Connecticut & Active \\
\hline Alaska & Not Active & Delaware & Active \\
\hline Colorado & Not Active & Illinois & Active \\
\hline Florida & Not Active & Maine & Active \\
\hline Georgia & Not Active & Maryland & Active \\
\hline Hawaii & Not Active & Massachusetts & Active \\
\hline Idaho & Not Active & Michigan & Active \\
\hline Indiana & Not Active & New Hampshire & Active \\
\hline Iowa & Not Active & New Jersey & Active \\
\hline Kansas & Not Active & New York & Active \\
\hline Kentucky & Not Active & Ohio & Active \\
\hline Louisiana & Not Active & Pennsylvania & Active \\
\hline Minnesota & Not Active & Rhode Island & Active \\
\hline Mississippi & Not Active & Texas & Active \\
\hline Missouri & Not Active & Arizona & Suspended \\
\hline Nebraska & Not Active & Arkansas & Suspended \\
\hline North Carolina & Not Active & California & Suspended \\
\hline North Dakota & Not Active & Montana & Suspended \\
\hline Oklahoma & Not Active & Nevada & Suspended \\
\hline South Carolina & Not Active & New Mexico & Suspended \\
\hline South Dakota & Not Active & Oregon & Suspended \\
\hline Tennessee & Not Active & Virginia & Suspended \\
\hline Utah & Not Active & & \\
\hline Vermont & Not Active & & \\
\hline Washington & Not Active & & \\
\hline West Virginia & Not Active & & \\
\hline Wisconsin & Not Active & & \\
\hline Wyoming & Not Active & & \\
\hline
\end{tabular}

Source: US EIAa, 2009. 


\section{Annex 8 - Electricity Savings Charts for APP Countries}

\section{Figure A-1 Electricity Savings Potential for Australia}

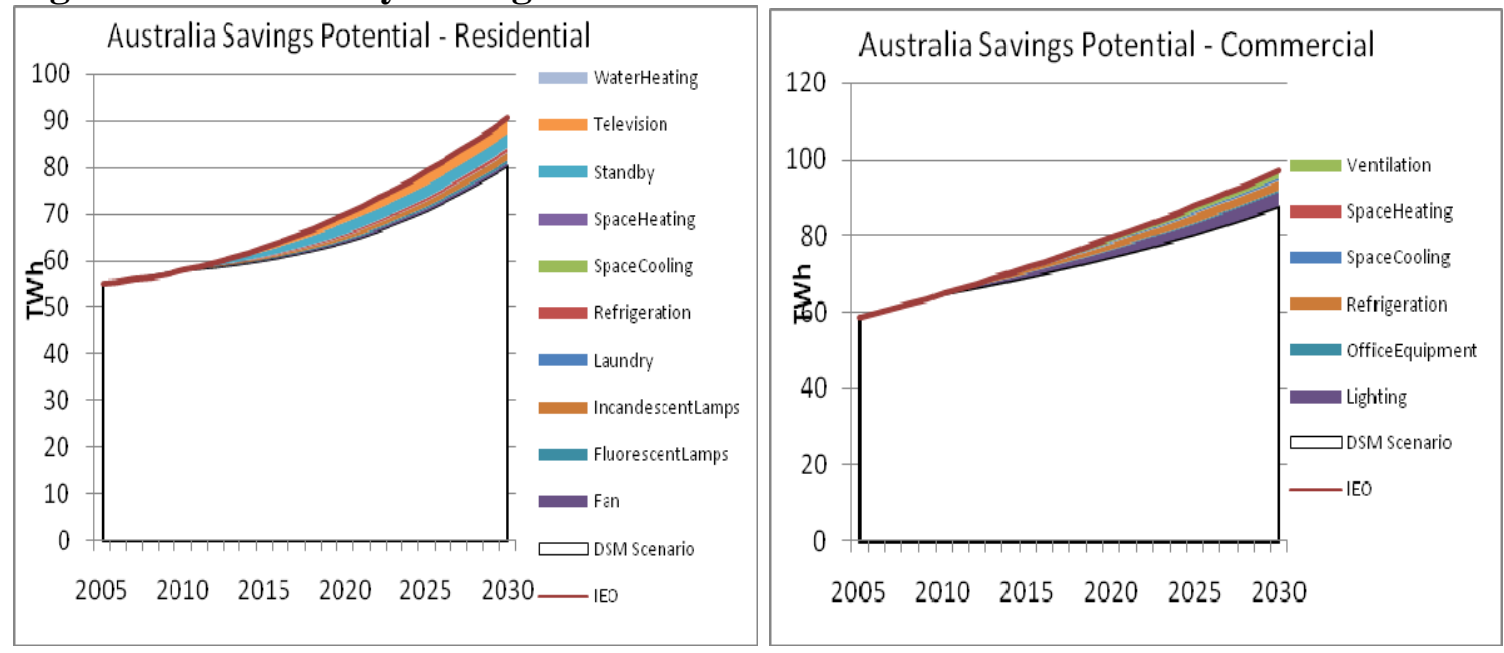

Figure A-2 Electricity Savings Potential for Canada
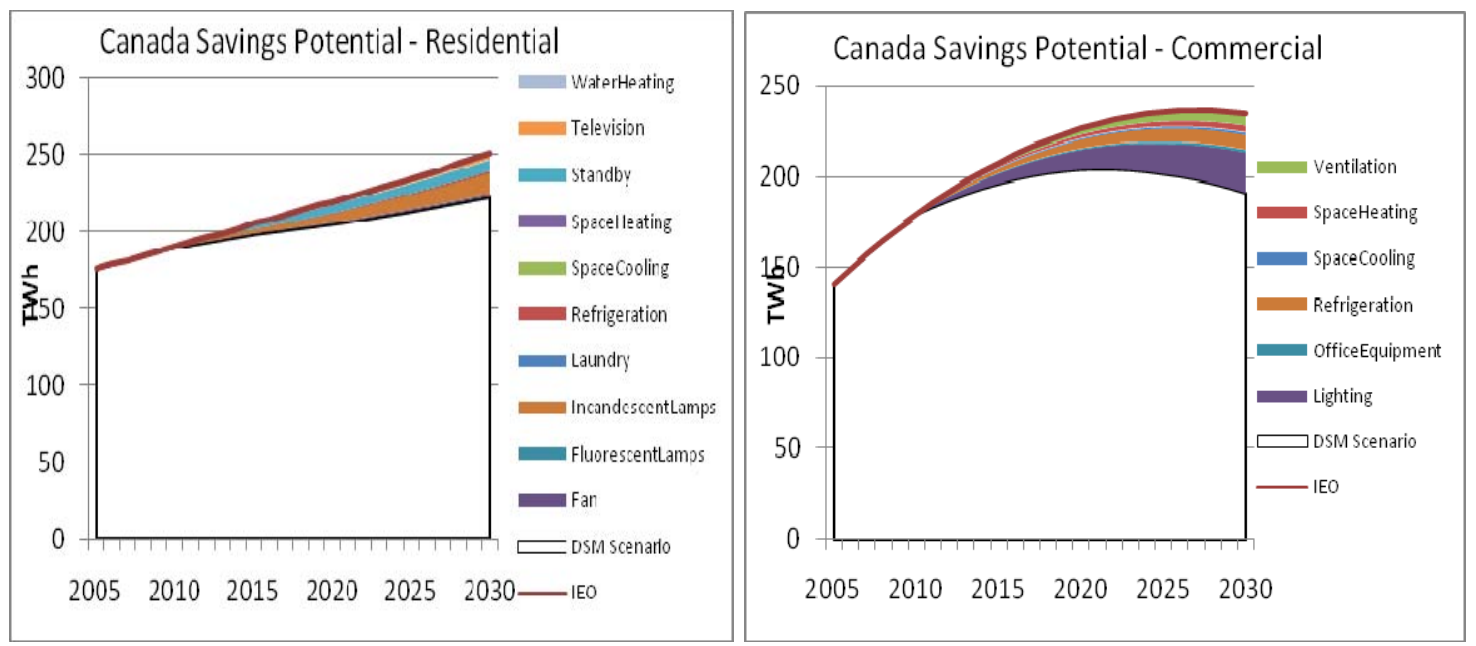

Figure A-3 Electricity Savings Potential for China
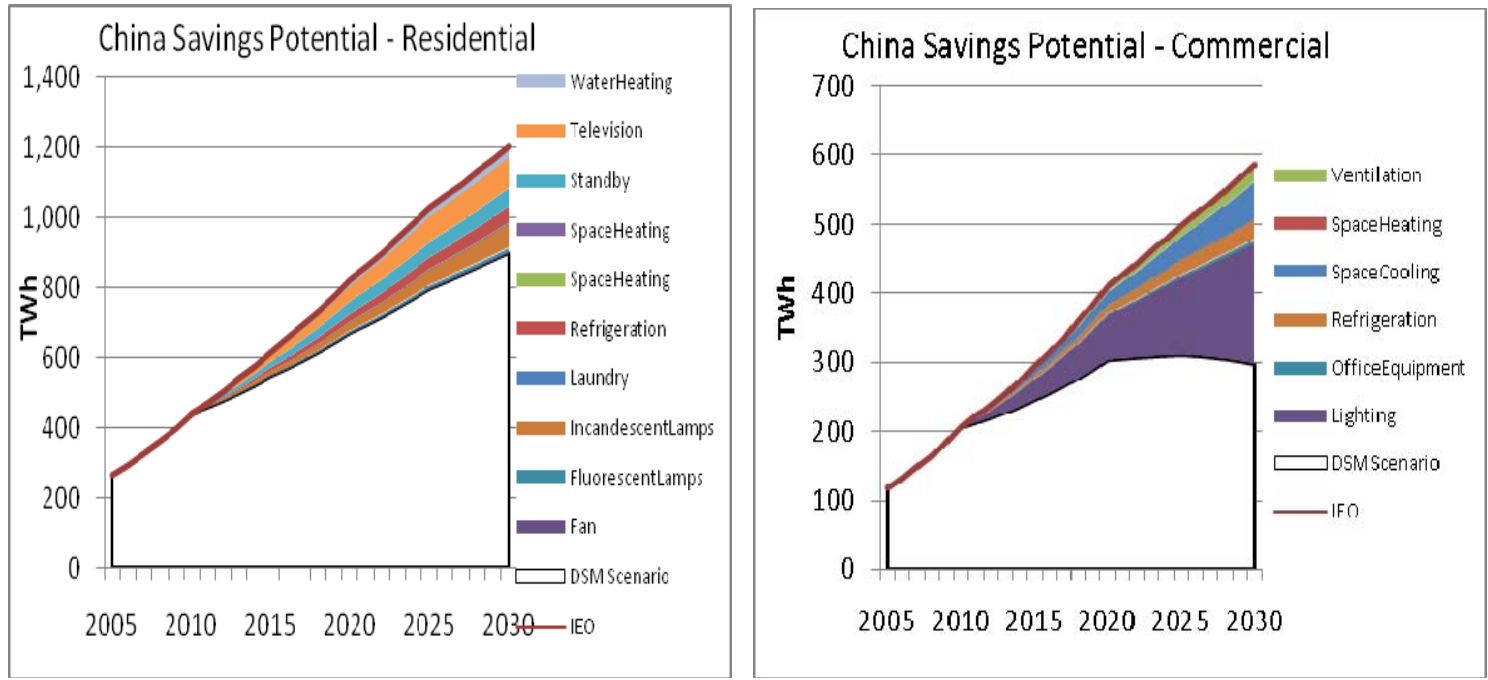
Figure A-4 Electricity Savings Potential for India
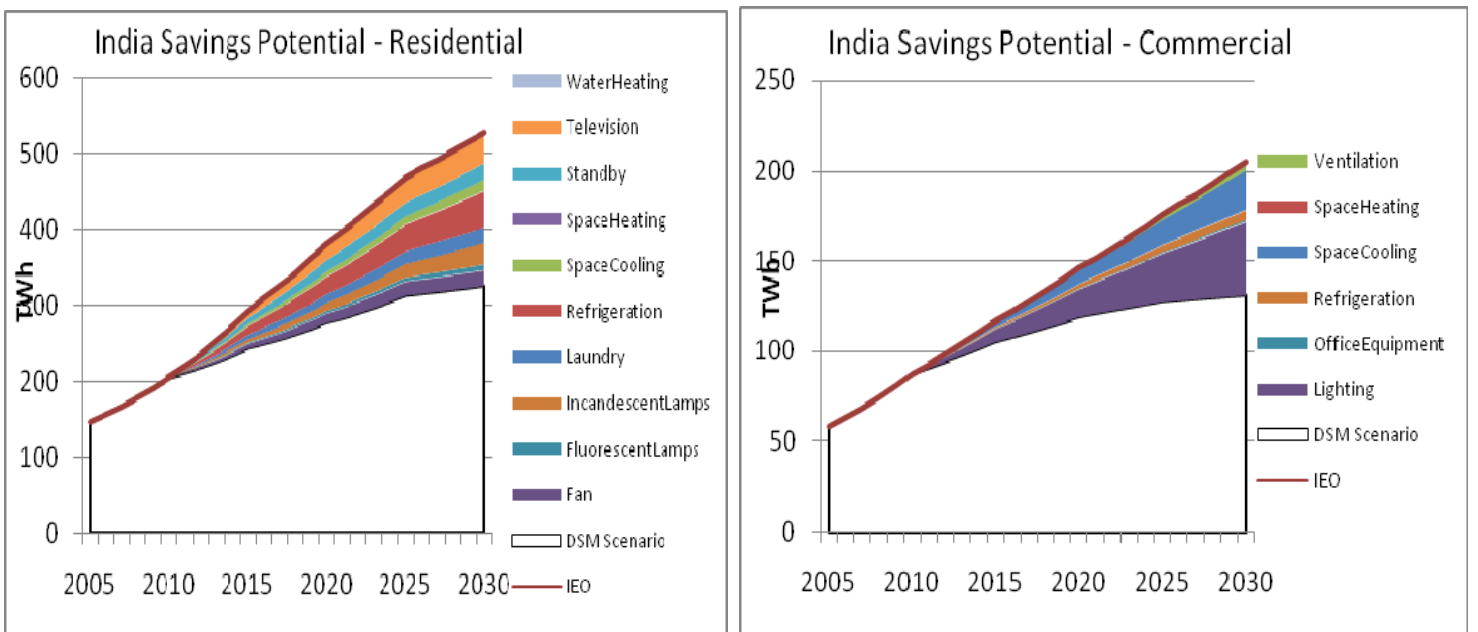

\section{Figure A-5 Electricity Savings Potential for Japan}
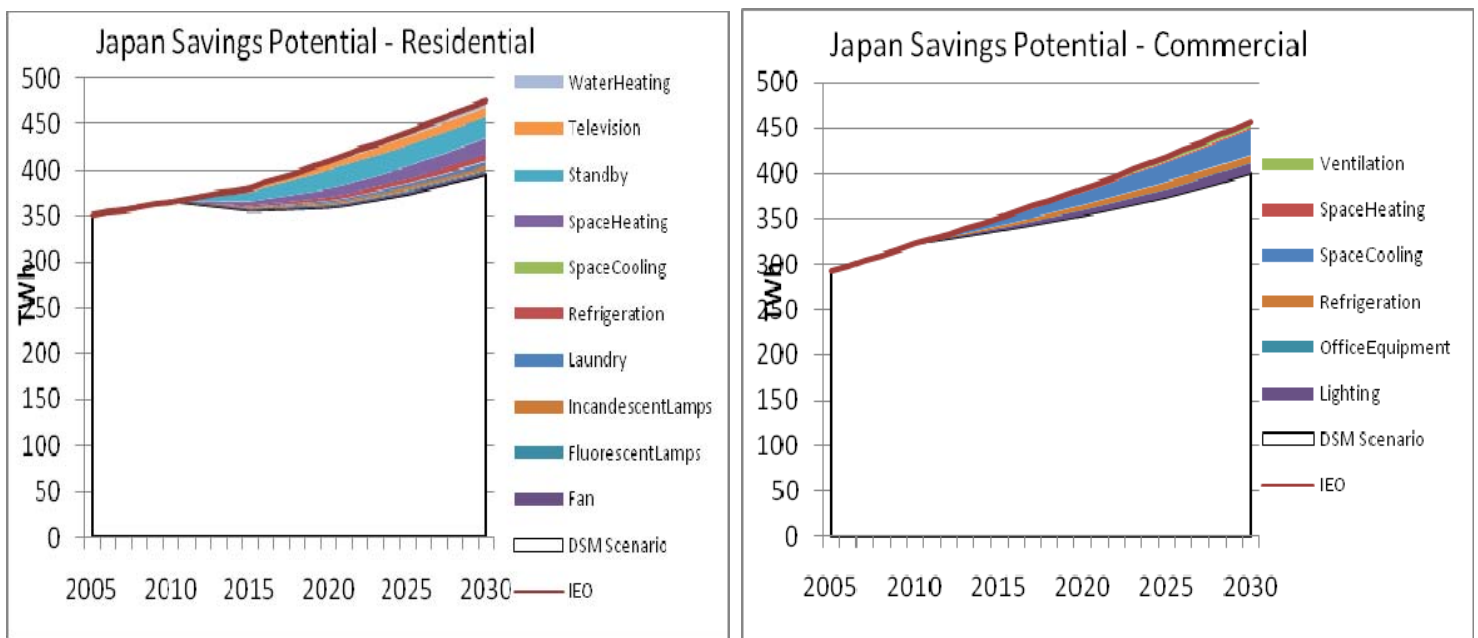

\section{Figure A-6 Electricity Savings Potential for Korea}
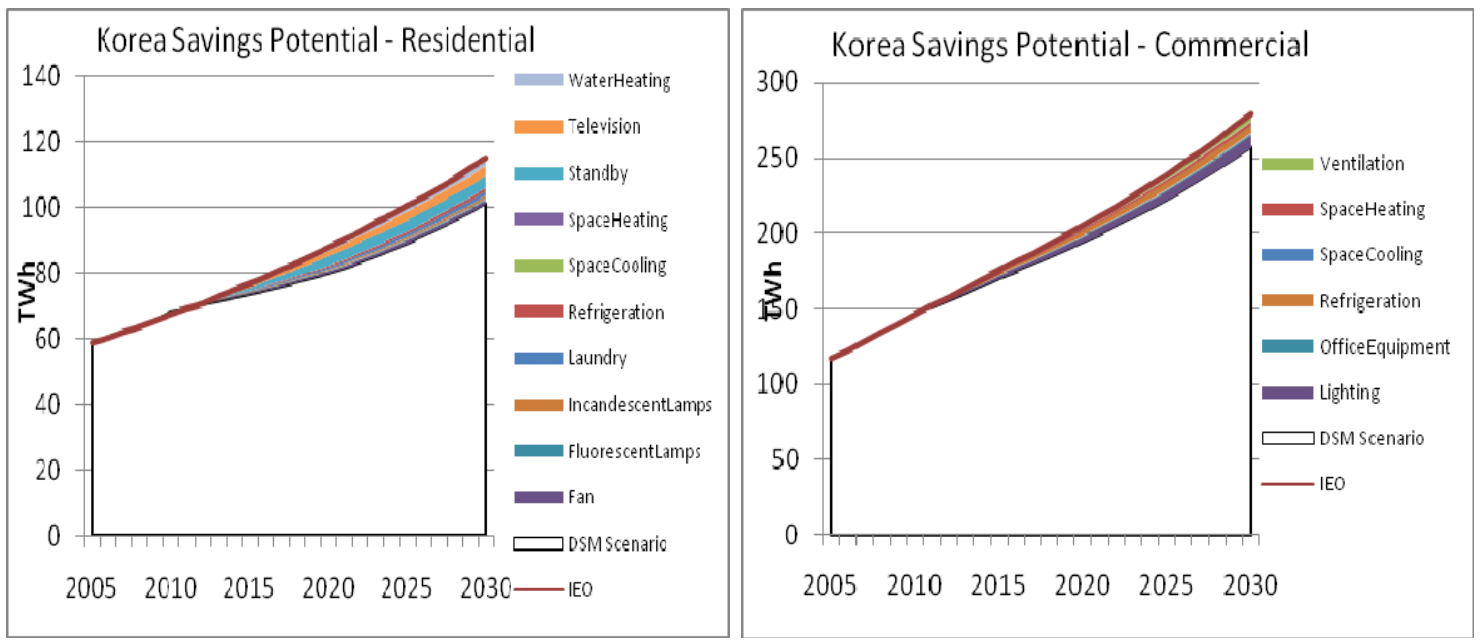
Figure A-7 Electricity Savings Potential for the United States

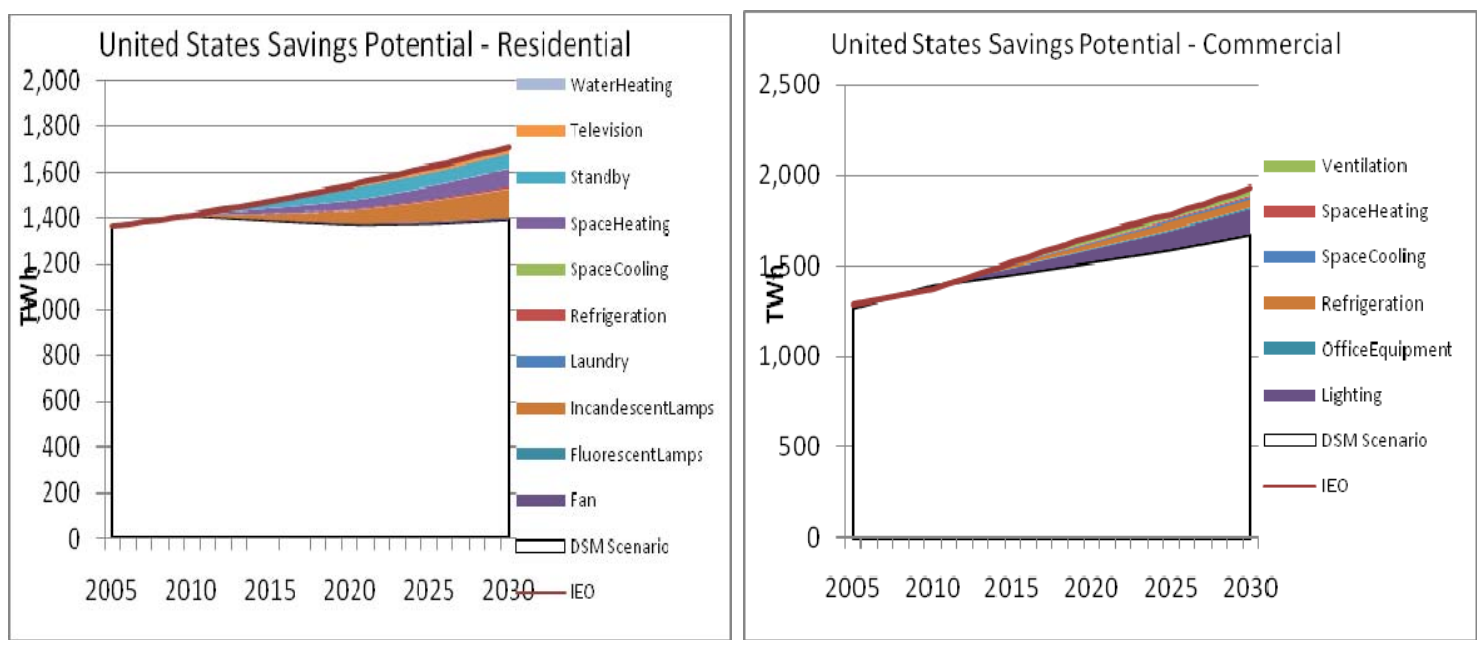

